\title{
Norma e Desvio em Comunidades de Antigo Regime
}

\author{
Bruno Filipe Gonçalves de Almeida \\ brunoalmeida07@outlook.pt
}

\section{Resumo}

A Europa da Época Moderna é marcada por profundas mudanças a nível económico, político, cultural e social. Estas alterações vão repercutir-se localmente nas comunidades do Antigo Regime, ao longo dos séculos XVII e XVIII. É neste contexto, de profundas alterações, que este trabalho pretende enquadrar algumas tendências identificadas nos comportamentos sociais dessas comunidades, quando analisadas ao nível da paróquia e dessa forma identificar agentes, espaços e laços que definiam estas comunidades. Este trabalho irá focar-se numa comunidade paroquial do bispado do Porto, em Portugal, no período de 1607 a 1794.

$\mathrm{O}$ trabalho visa também analisar os comportamentos de dois mundos, o da Igreja e o dos Crentes, em interseção, através de informações coligidas em dois tipos de fontes: os livros de visitas paroquias e as constituições sinodais. Com estas fontes pretendemos compreender o que era imposto pela Igreja em termos sociais, e quais os traços das sociabilidades destas comunidades.

O Concílio de Trento teve uma importância assinalável, quer no âmbito da reestruturação da Igreja, quer no do disciplinamento social. Dada a relevância deste Concílio, um dos objetivos do trabalho é o de analisar se, cerca de dois séculos depois do Concílio, as suas normas estavam interiorizadas. De que maneira é que estas populações se comportavam face à vigilância eclesiástica? As ações destas comunidades espelhavam os objetivos de Trento?

Com este percurso, o trabalho irá debruçar-se sobre laços de sociabilidade em "pequenos mundos", o das paróquias, onde os crentes organizavam o seu quotidiano e geriam formas de sociabilidade, conflitos, rivalidades e convivências.

Palavras Chave: Sociabilidades; Comportamentos; Comunidades Paroquiais; Visitas Pastorais; Disciplinamento Social.

\begin{abstract}
Early Modern Europe is characterized by economic, political, cultural and social changes. These changes have noticeable impact on the European communities of the Ancien Regime, throughout the 17th and 18th centuries. The focus of this paper is Portugal and its parish communities. The paper wants to identify some trends in the social behaviour of communities at a parish level, to understand which agents, spaces and relations defined these communities.

This work also aims analyzing the behaviors of two worlds - the one of the Church and the Believers -in their coexistence through information collected from two sources: parish visit books and diocesan constitutions. With these sources, we intend to understand what was imposed by the Church in terms of social behavior, and which was the real sociability in these communities.

The Council of Trent was of considerable importance, both in terms of restructuring the Church and in terms of social discipline. To remark this important landmark in Western history, our goal is to apprehend what really changed in terms on behavior and surveillance by the Church two centuries after its Decrees. Were its norms adopted and practiced? How did people behave when facing ecclesiastical vigilance? Were the norms and orientations of the Concil a reality?

Focusing on small worlds, the paper will focus on the analysis of communities' behavior, and on the spaces in which they organized their daily lives.
\end{abstract}

Keywords: Sociabilities; Behaviors; Parish Communities; Parish Visits; Social Discipline. 


\section{Introdução}

O presente trabalho está diretamente relacionado com temáticas de história social e religiosa, ao pretender questionar como eram definidas as sociabilidades em sociedades de Antigo Regime. O objetivo deste trabalho é o de identificar os agentes, os locais e as ações de um conjunto de indivíduos que conviviam em comunidades paroquias. É necessário ter em linha de conta que a paróquia era um centro de sociabilidade e de enquadramento privilegiado das comunidades europeias ao longo da época moderna. $\mathrm{O}$ "sentimento de pertença" é associado por estas populações às suas paróquias e não propriamente ao conceito de "Nação" (conceito que só é utilizado no século XIX).

Logo, queremos compreender qual era a norma imposta por parte da Igreja aos comportamentos destas comunidades e quais as suas práticas. Para tal, iremos cruzar as informações dos livros de visitas pastorais de Gulpilhares, Canelas, Olival, Crestuma e Pedroso com as Constituições Diocesanas do Bispado do Porto de D. João de Sousa, que cobrem o período de 1607 a 1794.

A escolha do tema e das fontes parte do universo de estudo vasto que vem sendo trabalhado por autores como Joaquim Ramos de Carvalho ${ }^{1}$, Franquelim Neiva Soares ${ }^{2}$, José Pedro Paiva ${ }^{3}$, Isaías da Rosa Pereira ${ }^{4}$, Eugénio dos Santos $^{5}$ entre outros autores, que se revelaram fulcrais para este exercício de pesquisa.

Ao propor esta temática consideramos algumas questões como ponto de partida para as quais dirigimos o processo de investigação. Assumindo as paróquias como um espaço de sociabilidade no Antigo Regime, em que medida as normas tridentinas seriam cumpridas nessas comunidades de Antigo Regime? Seriam os Livros de Visitas e as Constituições Diocesanas um mecanismo de disciplinamento social? O que era imposto pelas visitações seria cumprido pelos crentes? De que natureza seriam as medidas da Igreja para controlar os comportamentos dos crentes?

O intuito é o de comparar os dados das visitações com as normas diocesanas inserindo-as numa base de dados estruturada, segundo algumas variáveis de análise, que adiante se identificam.

\footnotetext{
${ }^{1}$ CARVALHO, Joaquim Ramos de - Comportamentos morais e estruturas sociais numa paróquia de antigo regime: Soure, 1680-1720: reconstituições, interpretações e metodologias. Coimbra: Faculdade de Letras da Universidade de Coimbra, 1997. Dissertação de Doutoramento em História Moderna. pp. 3-39.

${ }^{2}$ SOARES, A. Franquelim S. Neiva - "A sociedade do antigo regime nas visitações e inquéritos paroquiais do distrito de Braga: I - Abação (S. Cristóvão)”. Revista Theologica. Vol. 13 (1979) pp. 429-565.

${ }^{3}$ PAIVA, José Pedro; CARVALHO, Joaquim - "A evolução das visitas pastorais da diocese de Coimbra nos séculos XVII e XVIII”. Ler História. N. ${ }^{\circ} 15$ (1989) pp. 29-41.

${ }^{4}$ PEREIRA, Isaías da Rosa - "Visitas Paróquias dos Séculos XIV, XV e XVI”. Lusitania Sacra. 2a série, Tomo IV (1992) pp. 311-344.

${ }^{5}$ SANTOS, Eugénio dos - "Os livros das visitas pastorais da região portuense: questões e perspectivas de abordagem”. Revista de História. N. ${ }^{\circ} 2$ (1979) pp. 237-244.
} 
Seguidamente, trabalharemos esses dados em tabelas e gráficos. Agentes, locais e comportamentos, na sua vertente de prática e norma, são dimensões de análise privilegiadas nesta bordagem empírica de alguns "pequenos mundos".

Ao trabalhar com fontes históricas, temos que ter em conta a sua natureza e os objetivos da sua produção. Ambas as fontes que utilizaremos são de natureza religiosa e produzidas por agentes da Igreja Católica, por clérigos. Esta salvaguarda é necessária para reconhecer que as fontes apresentam limitações, quer no que se refere à informação que disponibilizam, quer no que toca às suas intenções. Assim, torna-se necessário questionar estas fontes, tendo em conta as dificuldades em trabalhar dimensões quantitativas quando aplicadas a áreas da História Religiosa e Social no período moderno ${ }^{6}$.

Ambas as fontes foram produzidas pela entidade Igreja, com objetivos distintos, mas que se complementam. A dimensão religiosa nas suas vertentes doutrinal e ética está presente nos livros de visitas; a normatividade eclesiástica está plasmada nas constituições diocesanas e confronta-se e condiciona outro tipo de normatividade: a laica ou consuetudinária.

As várias leituras dos dados apresentados nas duas fontes podem, por um lado, destacar aspetos que ainda não foram identificados por outros autores e por outro, permitem comparar as conclusões que delas possamos extrair com os estudos já efetuados pelos autores citados ao longo deste percurso de pesquisa e tratamento das informações.

Na sequência desta explicação, o presente trabalho será dividido em três capítulos. Um primeiro capítulo visa o enquadramento geral da temática, definindo o quadro teórico e as problemáticas de estudo. O segundo capítulo foca-se nos universos de estudo, esboçando os seus contornos no espaço e tempo. Por fim, o último capítulo contempla a abordagem analítica dos dados recolhidos no processo de investigação.

\section{Dos grandes aos pequenos mundos: da universalidade católica às comunidades paroquiais}

Com o presente capítulo, o trabalho pretende inserir o leitor na vasta conjuntura histórica que envolve a História de Portugal e da Europa na Época Moderna, no que diretamente se relaciona com o tema estudo, evocando a esfera religiosa na sua interação com a esfera social.

\footnotetext{
${ }^{6}$ GODINHO, Vitorino Magalhães - A História Social: Problemas, Fontes e Métodos. Colóquio da Escola Normal Superior de Saint-Cloud (15-16 de Maio de 1965). Trad. Maria Antonieta Magalhães Godinho. Lisboa: Edições Cosmos, 1973.
} 
Sabemos que ao longo dos séculos XVI a XVIII o mundo católico passou por várias mutações de cariz reformista. A Reforma Católica abarcou não só os seus os clérigos, mas também os crentes, dos mais privilegiados aos do Terceiro Estado ${ }^{7}$.

As reformas a que assistimos por parte da Igreja Católica iriam atuar por um lado sobre a formação, atitudes e comportamentos do Clero, mas pelo outro lado irá ter alguns reflexos nos "pequenos mundos" paroquias ${ }^{8}$. Torna-se necessário referir, para medir os seus impactos, que as sociedades de Antigo Regime eram profundamente ligadas à religião e consequentemente ao universo eclesiástico, desde o pároco aos bispos ${ }^{9}$.

A estas reformas estão inerentes um conjunto de processos e mecanismos que visam o disciplinamento social dos leigos e dos clérigos. Estas práticas são naturalmente observadas no nosso estudo de caso, em Portugal, mas também são reproduzidas e aplicadas no contexto ibérico e extraeuropeu. As visitas pastorais eram assim utilizadas no mundo ultramarino, mas também por a coroa espanhola ao longo da época moderna, como mecanismo de vigilância social. ${ }^{10}$

De igual modo, o universo dos crentes vai ser sujeito às novas normas de vigilância $\mathrm{e}$ disciplinamento impostas pelos vários movimentemos do mundo católico e desde logo prescritas pelo Concílio de Trento, marco maior dessa Reforma. Deste modo, os “pequenos mundos" que eram as paróquias, unidades de enquadramento das populações de toda a Europa e de Portugal, vão ser em última análise o foco principal de atuação deste movimento reformista da esfera cristã ${ }^{11}$.

Já ao longo do século XVI e até antes dos decretos do Concílio de Trento serem aplicados, os movimentos reformistas da Igreja eram sentidos por toda a Europa, inclusive na área do disciplinamento do Clero e da sua ação pastoral ${ }^{12}$. Contudo, apesar destas ações precoces atuarem em diversas direções e em problemas específicos, os decretos tridentinos foram fundamentais para o sucesso dos mecanismos que se irão tentar implementar nos tempos subsequentes ${ }^{13}$.

São várias as obras historiográficas que vão tocando na temática proposta, abrindo espaço aos debates e à exposição das diferentes abordagens de sociabilidades, desvios e normas, em sociedades de Antigo Regime. Destas destacamos os contributos, diferentes entre si, de

\footnotetext{
${ }^{7}$ MATTOSO, José (dir.) - No Alvorecer da Modernidade (1480-1620), Vol. 3 de MAGALHÃES, Joaquim Romero (coord.), "História de Portugal". Lisboa: Editorial Estampa, 1997.

${ }^{8}$ AZEVEDO, Carlos A. Moreira (dir.) - Humanismos e reformas, Vol. 2 de MARQUES, João Francisco, e GOUVEIA, António Camões (coord.). "História religiosa de Portugal". Lisboa: Círculo de Leitores, 2000-2002. pp. 20-26.

9 Ibidem.

${ }^{10}$ PAIVA, José Pedro - "Pastoral Visitations in the First World Empires (Spain and Portugal in the 16th and 17th Centuries): A Comparative Approach". Journal of Early Modern History. Vol. 24, n. ${ }^{\circ}$ 3. pp. 224-252.

${ }^{11}$ AZEVEDO, Carlos A. Moreira (dir.) - Humanismos e reformas, Vol. 2... pp. 20-26.

${ }^{12}$ Ibidem.

${ }^{13}$ Ibidem.
} 
Eugénio dos Santos $^{14}$, Franquelim Neiva Soares ${ }^{15}$, Isaías da Rosa Pereira ${ }^{16}$ e os mais recentes de José Pedro Paiva ${ }^{17}$, Joaquim Carvalho ${ }^{18}$, Lisbeth Silva ${ }^{19}$.

As ações de reforma referidas, aplicadas diretamente nas paróquias e seus quotidianos, necessitaram de suportes e de mecanismos que visavam o disciplinamento destes crentes aos olhos da Igreja Católica. Serão esses mecanismos e momentos chave deste movimento de reforma católica que a pesquisa irá analisar nos capítulos seguintes, centrando-se nas paróquias de Gulpilhares, Canelas, Olival, Crestuma e Pedroso. Do mesmo modo, procurar-se-á compreender como é que as populações locais interagiram, reagiram ou responderam a estas imposições normativas.

\subsection{A Normatividade tridentina dois séculos depois}

Para melhor compreensão dos significados e ações de Trento nos crentes e seu impacto nas sociabilidades e comportamentos dos fiéis na Época Moderna, convém refletir sobre alguns conceitos pertinentes para esta explanação. Conceitos estes que abrem possíveis caminhos para compreender como é que a Igreja imprimia o cunho da sua doutrina nas vivências dos habitantes em certas paróquias; e em que medida estes crentes estabeleciam entre si comportamentos que eram naturais para o seu entendimento, mas que deveriam ser sancionados pelos costumes e normas católicas.

A primeira definição prende-se com as visitas pastorais. Mas do que tratamos quando nos referimos a visitas pastorais? Segundo José Pedro Paiva, esta questão não está devidamente cuidada pela historiografia. A pouca atenção que os estudos históricos religiosos deram a este processo, deve-se "à decomposição e desaparecimento da maior parte do gigantesco espólio documental que este instituto foi produzindo no decurso de mais de três séculos (...)"20.

Os Livros de Visitas, corpo documental que retinha as informações registadas por uma certa visita pastoral, foram sendo pouco trabalhados e preservados ao longo do tempo, levando, por conseguinte, ao grande desconhecimento da prática dessas visitas no Portugal da Época Moderna ${ }^{21}$.

\footnotetext{
${ }^{14}$ SANTOS, Eugénio dos - "Os livros das visitas pastorais da região portuense: questões e perspectivas de abordagem.”... pp. 237-244.

${ }^{15}$ SOARES, A. Franquelim S. Neiva - "A sociedade do antigo regime nas visitações e inquéritos paroquiais do distrito de Braga: I - Abação (S. Cristóvão)”... pp. 429-565.

${ }^{16}$ PEREIRA, Isaías da Rosa - "Visitas Paróquias dos Séculos XIV, XV e XVI”... pp. 311-344.

${ }^{17}$ PAIVA, José, Pedro - "Os bispos e a Inquisição portuguesa (1536-1613)". Lusitania Sacra. Lisboa: Centro de Estudos de História Religiosa - Universidade Católica Portuguesa. 2. ${ }^{a}$ Série, Tomo 15, (2003) pp. 43-76. PAIVA, José Pedro; CARVALHO, Joaquim - "A evolução das visitas pastorais da diocese de Coimbra nos séculos XVII e XVIII"... pp. 29-41.

${ }^{18}$ CARVALHO, Joaquim Ramos de - Comportamentos morais e estruturas sociais numa paróquia de antigo regime...

${ }^{19}$ SILVA, Lisbeth Marilin Santos da - As visitas pastorais na diocese do Porto: (1675-1800): os comportamentos desviantes censurados. [Em Linha] Porto: [Edição de Autor], 2007. Dissertação de Mestrado.

${ }^{20}$ AZEVEDO, Carlos A. Moreira (dir.) - Humanismos e reformas, Vol. 2... pp. 250-251.

${ }^{21}$ Ibidem.
} 
Este processo de visita ficou assim registado em vários documentos, incluindo as constituições diocesanas, aqui sob a forma de norma. Estas constituições também vão ser um tópico de análise fulcral para comparar as ações que eram praticadas e registadas nos livros, com as normas de conduta explicitas nas constituições. Segundo o mesmo autor:

\begin{abstract}
A visita teria assim sido um importante meio de difusão por todo o território diocesano da doutrina da Igreja (para este efeito, por vezes, os prelados ou seus visitadores faziam-se até acompanhar de pregadores) e da pastoral dos bispos, um instrumento de verificação do funcionamento administrativo, económico e espiritual das igrejas e do desempenho do pessoal eclesiástico a elas adstrito (corpo que na maioria das freguesias não era apresentado pelo próprio prelado), e ainda um mecanismo de controlo da observância religiosa das populações bem como dos seus comportamentos em tudo o que pudesse ofender a moral (através da denúncia dos «pecados públicos») ${ }^{22}$.
\end{abstract}

Contudo, é de mencionar que estes processos de visitas já eram utilizados desde tempos medievais, e assim vão aumentando o seu ritmo e sua ação ao longo da Época Moderna, inclusive durante e após o Concílio de Trento, $1545-63^{23}$. Do século XVI para o século XVII o crescimento da ocorrência destas visitas é bastante significativo, em particular entre a década de 40/50 do século XVII ${ }^{24}$.

Como aconteciam estas visitas pastorais? Primeiramente era enviado um representante dos bispos às paróquias que anotava questões do foro espiritual e religioso dessa paróquia no livro de visitas. No caso das visitas portuguesas, destacamos os vários comportamentos do clero e crentes, mas também a prática de "pecados públicos" por parte destes fregueses. Um segundo aspeto interessante é que as testemunhas a serem inquiridas pelo visitador eram escolhidas ao acaso, a partir da lista de róis de confessados, em vez de ser o pároco local escolhê-las, demonstrando assim o aumento do poder do bispo dentro questões costumeiras dos locais ${ }^{25}$.

Compreende-se por isso que este processo comece a ser mais utilizado aquando a realização de Trento. Do mesmo modo, desde então envolvia um grande número de pontos a registar e observar, de acordo com os vastos domínios e normas da Igreja Católica e, em última instância, do estipulado pelos decretos tridentinos presentes nas constituições diocesanas.

Nesta matéria também é de igual modo importante salientar a dimensão de análise desta temática. Em primeiro lugar, a dimensão macro, ou seja, a integração dos decretos tridentinos na sociedade de Antigo Regime; a cultura religiosa de vigilância presente nas vidas das pessoas, na longa duração ${ }^{26}$. A nível micro, e aplicado aos "pequenos mundos" da vida nas paroquias,

\footnotetext{
22 Ibidem

${ }^{23}$ PEREIRA, Isaías da Rosa - "Visitas Paróquias dos Séculos XIV, XV e XVI"... pp. 311-344.

${ }^{24}$ AZEVEDO, Carlos A. Moreira (dir.) - Humanismos e reformas, Vol. 2... p. 253.

${ }^{25}$ Idem, pp. 251-252.

${ }^{26}$ CARVALHO, Joaquim de - "Micro-Historical Perspectives on Moral Choice: Case Studies from Early Modern Portugal". E-Journal of Portuguese History. [Em Linha] Rhode Island: Brown University; Porto: Universidade do Porto. Vol.2, n. ${ }^{\circ} 2$ (2004) pp. 1-18.
} 
podemos fazer vastas caminhadas e tentar compreender as relações socias e os laços estabelecidos entre pequenas comunidades locais ${ }^{27}$. Esta análise in loco, permite uma perceção e amostragem mais concreta para tecer e relacionar possíveis problemáticas socias com a esfera religiosa.

Relativamente às constituições diocesanas podemos defini-las como:

(...) leis de bases que são, significam um instrumento de trabalho precioso, quiçá indispensável, a quem cura de estudar os princípios em que assentava a organização institucional da Igreja em cada Diocese, as normas por que se regiam as diversas atividades eclesiásticas e as pessoas nelas envolvidas e (...), as regras do bom viver cristão. ${ }^{28}$.

A partir desta definição compreendemos a dimensão normativa que está presente nesta fonte e que nos possibilita elementos fulcrais para compreender a vida e comportamentos das populações locais e do corpo eclesiástico - "as Constituições Sinodais, não sendo propriamente um relato e muito menos um retrato de comportamentos, permitem a (re)construção de verdadeiros modelos-padrão do modo de estar social quer de clérigos quer dos fiéis em gera"29.

Por último, podem tecer-se algumas considerações sobre a importância da ação tridentina, dois séculos depois, mais concretamente nos livros de visitações, e constituições diocesanas. Ambos os espólios documentais vão ser cruzados neste trabalho, visando enquadrar as problemáticas inicias no universo de estudo escolhido.

O Concílio de Trento, bem como o processo de visita cruzam ideias, normas e modelos de comportamento que a Igreja invoca e defende como corretos para a sociedade ${ }^{30}$.

Assim, é no pós-concilio tridentino que as ações da pastoral se vão disciplinando e aperfeiçoando os seus objetivos, do grande mundo católico às pequenas paróquias ${ }^{31}$.

As prerrogativas de Trento do ponto de vista jurisdicional contra os leigos e religiosos são uma das linhas de pensamento que enquadram o processo de pesquisa deste trabalho, assim como o de destacar este contributo de Trento nos processos de visitas pastorais portuguesas ${ }^{32}$.

\footnotetext{
${ }^{27}$ Ibidem.

${ }^{28}$ SILVA, Francisco Ribeiro da - "O Bispado do Porto à luz das constituições sinodais da época moderna: valores clericais e normas de comportamento." In Tempos e lugares de memória: homenagem a D. Domingos de Pinho Brandão. Actas Vol.1. [Em Linha] Aveiro: Centro de Estudos D. Domingos de Pinho Brandão [etc.]: 2002. p. 58. ${ }^{29}$ Ibidem.

${ }^{30}$ Veja-se esta dimensão do legado tridentino deve ser enquadrada nos objetivos e princípios estabelecidos nas visitas pastorais, como a afirmação da doutrina católica; a repressão dos maus comportamentos do corpo eclesiástico, o combate às superstições, a uniformização de liturgias; o controlo local dos hereges e minorias religiosas presente no mundo católico. AZEVEDO, Carlos A. Moreira (dir.) - Humanismos e reformas, Vol. 2... pp. 251-252.

31 "Os resultados concretos alcançados pelas visitas pós-tridentinas conhecem-se ainda com parcimónia e carecem de estudos que apliquem metodologias uniformes que permitam obter visões globais e comparativas", segundo José Pedro Paiva. Ibidem, p. 254.

${ }^{32}$ Ibidem.
} 


\subsection{A Comunidade Paroquial de Vila Nova e de Gaia}

$\mathrm{Na}$ Época Moderna, em Portugal estava presente uma extensa rede de estruturas administrativas e judiciais - exercendo poder económico, judicial, e social sobre os territórios que circundavam essas estruturas. Ao longo do país existiam cidades, vilas, concelhos, terras, julgados, coutos, honras, betrias, comendas e lugares ${ }^{33}$. Sobrepondo-se e envolvendo esta rede concelhia encontramos uma rede de senhorios, constituída por casas nobres e eclesiásticas, mas também uma malha eclesiástica ${ }^{34}$.

É nesta realidade que se insere a comunidade de Vila Nova e Gaia, tanto envolvida na malha do termo do Porto, como na malha eclesiástica do Bispo da Cidade do Porto. O Município de Vila Nova de Gaia era dividido em duas terras autónomas. Gaia recebeu Carta de Foral outorgada pelo rei D. Afonso III em 1255 seguindo-se Vila Nova, por D. Dinis, em 1288. Em 1383, no entanto, ambas foram integradas no julgado do Porto perdendo a sua autonomia ${ }^{35}$.

Esta realidade administrativa — o Julgado de Gaia — vai juntamente com Vila Nova perdendo autonomia com as intervenções régias. Em 1422 assiste-se à concessão de Gaia ao Porto por D. João I; em 1423 a jurisdição de Gaia recai sob ordens do Porto; em 1437 D. Duarte desanexa o lugar de Vila Nova e Gaia da correição da Extremadura e une-os à correição de Entre Douro e Minho ${ }^{36}$. Esta geografia, pertence, portanto, ao termo do Porto, desde o século XVI ao Liberalismo, com algumas mudanças verificadas em inícios do século XVIII ${ }^{37}$.

Não podemos falar de sobreposições entre estas divisões admirativas, uma vez que os limite do termo do Porto e da sua diocese integravam nos alvores da modernidade muitas áreas da diocese de Braga ${ }^{38}$. Todavia, Gaia e Vila Nova também eram envolvidas por vários coutos, sendo eles Grijó, Sandim, Crestuma, Pedroso, Seixezelo e Avintes, sendo terras que possuíam imunidade, ou seja, sem intervenção régia ${ }^{39}$.

No século XVII, estas realidades administrativas, tanto da esfera religiosa como municipal, encontram-se cobertas por estudos sobre o termo da cidade do Porto e sua

\footnotetext{
${ }^{33}$ MARQUES, A. H. de Oliveira; SERRÃO, Joel (dir.) - Portugal do renascimento à crise dinástica. Vol. 5 de DIAS, João Alves (coord.), "Nova História de Portugal". Lisboa: Editorial Presença, 1998.

${ }^{34}$ NETO, Margarida Sobral - "Senhorios e concelhos na época moderna: relações entre dois poderes concorrentes". In CUNHA, Mafalda Soares da; FONSECA, Teresa, (eds.) - Os Municípios no Portugal Moderno: Dos Forais Manuelinos às Reformas Liberais. [Em Linha] Lisboa: Edições Colibri, CIDEHUS-UE, 2005. pp. 149-165.

${ }^{35}$ O foral manuelino de Vila Nova de Gaya, 1518-2018. Ed. de Eduardo Vítor Rodrigues; Trad. Susana Guimarçaes; Transc. de Sónia Feirreia. Vila Nova de Gaia: Câmara Municipal de Vila Nova de Gaia, 2018.

${ }^{36}$ SANTOS, Cândido Augusto Dias dos - "Gaia do século XVI ao século XVIII: História Económica e Social”. In AA. VV. - História de Gaia. Vila Nova de Gaia: Câmara de Vila Nova de Gaia, 1985. pp. 321-438.

37 Ibidem. De referir que durante a Modernidade a própria rede paroquial estava também misturada com o tecido concelhio, sofrendo algumas mudanças. Assim, existe um acréscimo à paróquia de Olival - Lavadores, Ameal e Carvalhos - que eram do Couto de Pedroso e do termo do Porto, sendo assim englobados.

${ }^{38}$ RAMOS, Luís António Oliveira de - História do Porto. Porto: Porto Editora. 2000.

${ }^{39}$ Ibidem.
} 
administração que englobava, como observamos, as freguesias que diziam respeito a Vila Nova e a Gaia - o local de análise escolhido para este trabalho ${ }^{40}$. A geografia paroquial desta zona não se vai alterar muito do XVII para o XVIII, uma vez que o termo do Porto já vinha sendo fixando desde a Idade Média, ficando fixado pela reforma de Frei Marcos de Lisboa ${ }^{41}$.

Por fim, com esta evolução da circunscrição paroquial e administrativa pretende-se inserir a problemática no espaço estudado. Compreende-se que as malhas eclesiásticas e municipais se devem distinguir, estas coexistiam entre si e com vastas outras divisões de alcance administrativo. É nesta realidade que vivem as comunidades de Antigo Regime das regiões de Gaia e Vila Nova, tanto no domínio religioso como no secular.

\subsection{Enquadramento social-religioso e económico das paróquias}

Neste capítulo não se pretende esmiuçar em concreto cada uma das comunidades paroquias que se inserem nesta análise. $\mathrm{O}$ objetivo será traçar um pequeno enquadramento destas regiões, de modo a elucidar o leitor sobre alguns dados e obras que ajudem a compreender estas realidades religiosas.

Relativamente a Gulpilhares, existem vários dados de natureza religiosa, social e temporal presente nos próprios livros de visitas. A vasta panóplia de matérias e temas que podemos retirar dos livros de visitas são conhecidos pela historiografia. Contudo nem todos os autores dão a atenção necessária a estes estudos ${ }^{42}$. Do ponto de vista socioeconómico podemos tirar algumas ilações sobre esta realidade ao consultar fontes como as Memórias Paróquias ou as corografias portuguesas que nos fornecem uma vasta visão sobre esta região.

Uma das questões mais importantes para o conhecimento desta localidade poderá ser o capítulo de usos e costumes presente na documentação das visitas. Através deste testemunho, e com o cruzamento de outras possíveis fontes, podemos inferir vários reparos sobre a região. De resto, outras obras surgem com detalhes da região para épocas mais avançadas, mas não deixam de suscitar linhas de pensamento para a perpetuação dos comportamentos, ou práticas, na longa duração ${ }^{43}$.

No que diz respeito a Canelas, é possível mencionar alguns aspetos sobre os seus limites, existindo um documento antigo transcrito do pergaminho, no século XVI, que remete para a repartição entre as freguesias de Canelas e Pedroso ${ }^{44}$. Neste mesmo documento também se

\footnotetext{
${ }^{40}$ SILVA, Francisco Ribeiro da - O Porto e o seu termo 1580-1640: Os homens as instituições e o poder. Volume I. Porto: [Edição do Autor], 1985. pp. 57-81.

${ }^{41}$ Ibidem, pp. 57-81.

${ }^{42}$ Visitações de Gulpilhares. Ed. de Francisco Barbosa da Costa e João de Sousa. Vila Nova de Gaia: Câmara Municipal de Vila Nova de Gaia. Gabinete de História e Arqueologia, 1986.

${ }^{43}$ VALE, Carlos - A Freguesia de Santa Maria de Gulpilhares. Vila Nova de Gaia: Junta de Freguesia. 1987.

${ }^{44}$ No dito documento são descritos os limites das suas áreas, determinados pelas autoridades locais. Ver COSTA, Francisco Barbosa da - S. João Baptista de Canelas - notas monográficas... pp. 13-17.
} 
referem os limites entre Canelas, Vilar do Andorinho e Mafamude, ainda que seja no reverso do documento em letra do XVIII ${ }^{45}$. Existem outros documentos que nos falam desta realidade, mas presentes em análises dispersas ${ }^{46}$. Todavia, é possível retirar alguns dados sobre Canelas nos séculos XVII e XVIII, com base em documentação dispersa, sendo uma das fontes os livros de vistas. Em termos demográficos, observamos estudos que apontam para o aumento da população de Canelas do século XVII para o XVIII ${ }^{47}$.

Relativamente ao quadro económico e profissional de Canelas, este insere-se num mundo ligado à agricultura e ao artesanato. Algumas menções de pagamentos, nos usos e costumes da terra, remetem-nos para o seu caráter agrícola. Também surgem no século XVII e XVIII prazos e outros documentos que nos falam da existência de pedreiros, e exploração de pedreiras ${ }^{48}$.

No que toca aos aspetos religiosos, destacam-se as festas de S. João, S. Miguel e Tiago mencionadas em monografias e ensaios etnográficos, que esboçam os velhos costumes religiosos desta paróquia ${ }^{49}$ Pedroso, no século XVIII apresenta algumas configurações relatadas num interrogatório, mandado pelo bispo Frei António de Távora - é um Couto e freguesia do termo da cidade do Porto, onde a igreja paroquial se encontra no meio da freguesia e do Couto ${ }^{50}$. O quadro rural vai se destacando nesta paróquia face aos usos e costumes que identificamos em algumas paróquias ${ }^{51}$. Por conseguinte, análises à documentação religiosa permitem recolher informação precisa sobre estes “mundos”, que inferimos ao analisá-la ${ }^{52}$.

\footnotetext{
${ }^{45}$ Ibidem.

46 “(...) os limites entre Canelas, Perosinho e Serzedo e em alguns casos Gulpilhares são praticamente contíguos o que naturalmente dificulta a sua concreta demarcação (...) demonstrando-nos assim várias colidências entre estas freguesias, mas também muita dificuldade em as precisar, nestes tempos remotos." Ibidem.

${ }^{47}$ Ibidem, pp. 55-63; 93-117.

${ }^{48}$ Ibidem, pp. 125-140.

${ }^{49}$ Crestuma, Olival e Pedroso têm, de igual modo, algumas monografias que mencionam, tanto aspetos gerais, como alguns tópicos concretos destas regiões. No caso de Olival, temos a documentação dos livros de vistas, que é citada ao longo do trabalho, juntamente com as restantes freguesias, como primordial base para informações. Ver COSTA, Francisco Barbosa da - S. João Baptista de Canelas - notas monográficas. Canelas: Edição da Paróquia de Canelas, 1980. pp. 149-200.

${ }^{50}$ Ao longo do inquérito verificámos aspetos de vária ordem relativos às perguntas colocadas. A localidade encontrava-se ligada à agricultura e a outros mesteres, como carpinteiros, segundo constatamos numa ordenança de 1764. Relativamente às festividades referidas em Pedroso são a Páscoa, Natal, S. Miguel, festas que são recorrentes ao longo das restantes paróquias. Ver COSTA, Francisco Barbosa da - S. Pedro de Pedroso nos séculos XVIII e XIX. Câmara Municipal de Vila Nova de Gaia. Junta de Freguesia de Pedroso, 2000; e COSTA, Francisco Barbosa da - "Usos e Costumes nos livros de visitações de algumas freguesias de Gaia". Separata da Revista Gaia, vol. II. Vila Nova de Gaia: Gabinete de História e Arqueologia de Vila Nova de Gaia, 1984. pp. 281-290.

${ }^{51}$ Ibidem. A região de Crestuma é igualmente um couto, doado por D. Teresa a D. Hugo em tempos medievais e que permaneceria terra coutada na modernidade. A sua localização surge entre Olival e Lever. Tanto Olival como Crestuma têm ligações económicas à agricultura.

${ }^{52}$ Ver COSTA, Francisco Barbosa da - "Visitações da Igreja de Santa Maria de Olival, século XVIII". Separata da Revista Gaia, vol. I. Vila Nova de Gaia: Gabinete de História e Arqueologia de Vila Nova de Gaia, 1983; e COSTA, Francisco Barbosa da - "Usos e Costumes nos livros de visitações de algumas freguesias de Gaia”... pp. 281-290.
} 


\section{As Comunidades Paroquias: Gulpilhares, Canelas, Olival, Crestuma e Pedroso}

No que concerne à análise dos dados utilizamos uma grelha de análise para tratar os dados e respetivos indicadores. A recolha de dados foi realizada através da leitura de documentação já publicada em monografias, digitalizada e em suporte manuscrito. Os critérios de escolha de campos para a análise da informação na base Excel foram os seguintes: uma primeira folha onde consta o nome do visitador; pároco; ação dos fregueses ou crentes; categorização da ação sobre que incide o visitador - classificada como profissional, moral ou religiosa (profissões que devem ser vigiadas, costumes e atos tanto religiosos como leigos que são punidos os olhos da igreja); agentes sociais (mulher, fregueses, vendeiro, barbeiro e clérigo); espaços de sociabilidade (igreja, paróquia, festividades); tipologia da ação do crente identificada na visitação; data da visita; ação do visitador (punitiva ou preventiva) ${ }^{53}$.

Numa segunda folha, da mesma base Excel, inseri os dados referentes às constituições diocesanas, com menção ao livro, bispado, ano, tema da constituição, página, norma da constituição, agentes visados (clero ou crentes) e ação na norma diocesana (preventiva ou punitiva) ${ }^{54}$.

Esta escolha visa, por um lado, comparar os dados das diretivas da igreja na esfera social e religiosa com os dados registados nos livros de visitas das respetivas comunidades paroquias escolhidas para abordagem empírica. Assim, estas variáveis vão no sentido de esboçar considerações sobre os laços, espaços e agentes envolvidos nas questões de partida. Assim, nos próximos tópicos de abordagem serão tecidas as conclusões extraídas, em relação com a bibliografia da temática diretamente ligada às questões orientadoras do quadro teórico já estabelecido.

\subsection{Agentes Sociais Visados}

Neste tópico pretendemos identificar os vários agentes que se destacam pelas suas ações ao longo dos livros de visitas. O papel destes crentes vai sendo relevante na medida em que nos permite percecionar algumas linhas sobre o perfil destas sociedades no Antigo Regime.

Sabemos que vários estudos já abordam os comportamentos destes indivíduos e os seus graus de parentesco com o cruzamento de outras fontes históricas. Também existem dados para a região do Porto e Coimbra que identificam o cariz socioeconómico destas populações e seus

\footnotetext{
${ }^{53}$ Ver os Títulos da Vezita q pertence ao Deado do Porto-PT/ADPRT/DIO/CABIDO-01/1693, K/15/6/1 - 1693 (Arquivo Distrital do Porto); as Visitações de Gulpilhares...; e COSTA, Francisco Barbosa da - S. Pedro de Pedroso nos séculos XVIII e XIX...

${ }^{54}$ SOUSA, João de - Constituições sinodais do bispado do Porto. [Em Linha] Coimbra: Real Collegio das Artes da Companhia de Jesus, 1735.
} 
“pecados públicos", entre muitos outros aspetos ${ }^{55}$. Porém o nosso enfoque será numa análise mais circunscrita das cinco paróquias e tem por objetivo o reconhecimento desses fiéis. De igual modo, compreender se existem tendências desviantes e os seus laços de sociabilidades estabelecidos através das suas ações.

Comecemos por identificar a frequência com que determinados termos surgem, quando associados aos agentes visados pelas fontes que estudamos.

Gráfico 1 - Agentes Visados 1607-1794.

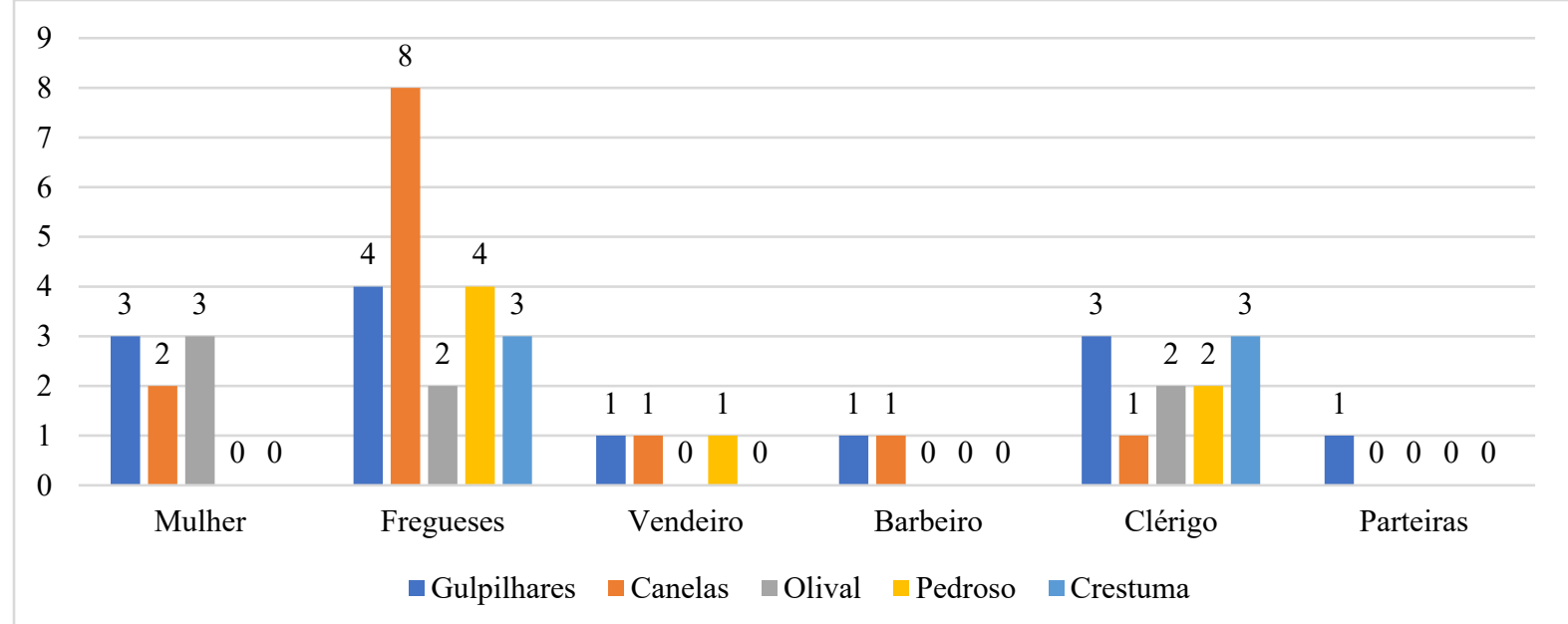

FONTE: Visitações de Gulpilhares. Ed. de Francisco Barbosa da Costa e João de Sousa. Vila Nova de Gaia: Câmara Municipal de Vila Nova de Gaia. Gabinete de História e Arqueologia, 1986; COSTA, Francisco Barbosa da - S. Pedro de Pedroso nos séculos XVIII e XIX.

Câmara Municipal de Vila Nova de Gaia. Junta de Freguesia de Pedroso, 2000; Títulos da Vezita q pertence ao Deado do PortoPT/ADPRT/DIO/CABIDO-01/1693 K/15/6/1 - 1693 (Arquivo Distrital do Porto).

Ao visualizarmos o Gráfico 1 constatamos que a definição "fregueses" é a que mais predomina no livro de visita da paróquia de Canelas. Isto significa que, mais do que particulares, as anotações ou deliberações são gerais, aplicáveis em grande medida à globalidade da comunidade. Entenda-se, porém, que englobamos todos os agentes que não tinha definição concreta na categoria de fregueses, como pertencentes à respetiva paróquia.

Também é curioso destacar a figura dos clérigos, que são um alvo dominante das preocupações por parte da Igreja, mas também muito identificados através das suas ações desviantes. Tal é o caso de "Sacerdotes com espingardas e armas", que surgem assim mencionados (criticados), em 1675, no Livro de Visitas de Gulpilhares. Portanto, ocorre também com o título "Padres usam palavras escandalosas", mencionado em 1643, no Livro de Visitas de Pedroso.

\footnotetext{
${ }^{55}$ CARVALHO, Joaquim Ramos de - Comportamentos morais e estruturas sociais numa paróquia de antigo regime... SILVA, Lisbeth Marilin Santos da - As visitas pastorais na diocese do Porto: (1675- 1800): os comportamentos desviantes censurados...
} 
Assim, com Trento observamos que esta preocupação, tanto com o clero e suas ações, como com os crentes, aumenta significativamente. Esta normatividade tridentina pode ser constatada através destes dados- tanto com a ação do visitador como com a identificação dos agentes visados nos livros de visitas ${ }^{56}$. Em Portugal, dois séculos depois deste concílio, as suas ações desviantes ainda são observadas neste universo e cronologia de estudo.

Com a questão do disciplinamento do clero presente nas normas tridentinas questionamos também esta realidade na ação do visitador sobre os clérigos, nas paróquias de Gulpilhares, Olival e Crestuma (Veja-se o Quadro 1 em anexo).

O grupo das "Mulheres" também reconhece clara importância, uma vez que nos pós Trento identificamos uma preocupação de combate à superstição e às questões de adultério, presentes também neste mundo católico português. Também com estes dados podemos confirmar esta leitura patente em trabalhos da historiografia que atentam sobre os comportamentos das mulheres. No caso de Gulpilhares destacamos a preocupação sobre as parteiras, por não batizarem as crianças no ato do parto ${ }^{57}$.

No caso de estudo, encontramos o registo de ações desviantes como ocorre em pequenos convívios como em festas, romarias ou procissões ${ }^{58}$. Esta é uma tendência que em nada diverge da historiografia, que refere encontros em locais públicos com homens e mulheres solteiras e uma grande atenção para as parteiras, como potenciais agentes desviantes ${ }^{59}$.

Vendeiros e barbeiros são também agentes de natureza profissional que são identificados ao longo do registo, como alvos de descompostura social, tanto em festas, como em procissões ou romarias. Que "Vendeiros não vendam vinho nos dias santos" estipula-se no Livro de Visitas de Crestuma de 1709. Que "vendeiros não vendam vinho aos domingos e dias santos" estipula-se em 1686, no Livro de Visitas e Gulpilhares. A sua atividade é muitas das vezes punida e proibida, por não seguirem as normas da pastoral ou da religião católicas. Relativamente aos barbeiros podemos destacar que a sua vigilância estava relacionada com a sua ação profissional, ou seja, as várias sangrias que eram proibidas "porque o padre local não administrava o Viático" 60 .

\footnotetext{
${ }^{56}$ POLÓNIA, Amélia - "A recepção do Concílio de Trento em Portugal". In GOUVEIA, António Camões; BARBOSA, David Sampaio; PAIVA, José Pedro (coord.) - O Concílio de Trento em Portugal e nas suas conquistas: olhares novos. Lisboa: Universidade Católica Portuguesa. Centro de Estudos de História Religiosa, 2014. pp. 41-58.

57 "Parteiras não examinam crianças no nascimento" - Visitações de Gulpinhares... 1676, fólio 80.

58 "Mulheres solteiras a assistirem a e juntarem-se em serões com homens vizinhos a ver" - Visitações de Gulpinhares... 1686, fólio 97. Exemplo semelhante em COSTA, Francisco Barbosa da - S. João Baptista de Canelas - notas monográficas... 1782.

${ }^{59}$ Ver PAIVA, José Pedro - Bruxaria e superstição num país sem "caça às bruxas": 1600-1774. 2. ed. Lisboa: Editorial Notícias, 2002.

${ }^{60}$ Visitações de Gulpilhares... pp. 20-25.
} 
Canelas e Gulpilhares destacam-se nesta análise de dados por envolverem em ações desviantes agentes das cinco classificações em números mais significativos. Logo, esta leitura permite destacar a riqueza desta mostragem na temática em conta.

Em Pedroso são maioritariamente identificados fregueses, vendeiros e clérigos como alvos da vigilância eclesiástica. As suas ações e interceções registadas na documentação denunciam aos olhos da Igreja certas sociabilidades punidas como atos desviantes, previstos nas normas de conduta das comunidades cristãs ${ }^{61}$.

Podemos assim concluir que certos grupos em sociedades de Antigo Regime eram mais vigiados do que outros agentes sociais. O corpo eclesiástico local das paróquias e alguns fregueses são apontados como possíveis agentes a denunciar e vigiar e disciplinar ${ }^{62}$. Para tal, várias medidas surgem durante os registos de visitas, que punem estes delitos e desvios, mas também que tentam destacar quem os comete. $\mathrm{O}$ incentivo à fiscalização das sociabilidades em comunidades paroquias, parece ser uma das grandes prioridades presentes nos livros de visitas e constituições diocesanas.

A natureza dos agentes, que são classificados e identificados em ambas os documentos sugerem a atenção da Igreja desde as convivências religiosas até aos comuns comportamentos do quotidiano.

\subsection{Práticas e Desvios}

No seguimento das abordagens, que foram explanadas nos capítulos anteriores, agora queremos focar-nos em aspetos relativos às ações praticadas pelos crentes, detendo a atenção na natureza dos desvios nas ações e na tipologia dessas ações, como variantes escolhidas para este estudo. A primeira dimensão, ou seja, os desvios são categorizados como sendo de natureza moral, religiosa ou profissional, de acordo com os registos levantados nos livros de visitas das cinco paróquias em análise.

A segunda dimensão diz respeito às práticas dos crentes, ou seja, às ações dos outros crentes que conduzem às denúncias dos desvios apontados. Centramo-nos em atos de denúncia ou vigilância, comportamentos que parecem ser incutidos pela normatividade da Igreja. Alguns estudos já têm se debruçado sobre esta questão de desvios e pecados públicos, tanto para a

\footnotetext{
61 "Denunciar pecadores" é a menção feita no Livro de Visitas de Pedroso de 1794, o que corresponde ao dever de denunciar nas visitações e ao juiz eclesiástico, previsto nas constituições sinodais, livro, assim como o dever de "denunciar os hereges", estipulado nas Constituições Sinodais do Bispado de D. João de Sousa.

${ }^{62}$ ALMEIDA, Fortunato de - História da igreja em Portugal. Nova edição preparada e dirigida por Damião Peres. Porto: Portucalense Editora, 1967-1968. Vol. 1 e Vol. 2.
} 
diocese portuense como para Coimbra ${ }^{63}$, todavia analisadas numa perspetiva mais macro, a nível diocesano.

As conclusões a que nós próprios chegamos encontram-se explícitas nos Gráficos 2 e 3, que representam a tipologia das ações e a natureza dos desvios.

Gráfico 2 - Natureza dos desvios nas ações dos crentes.

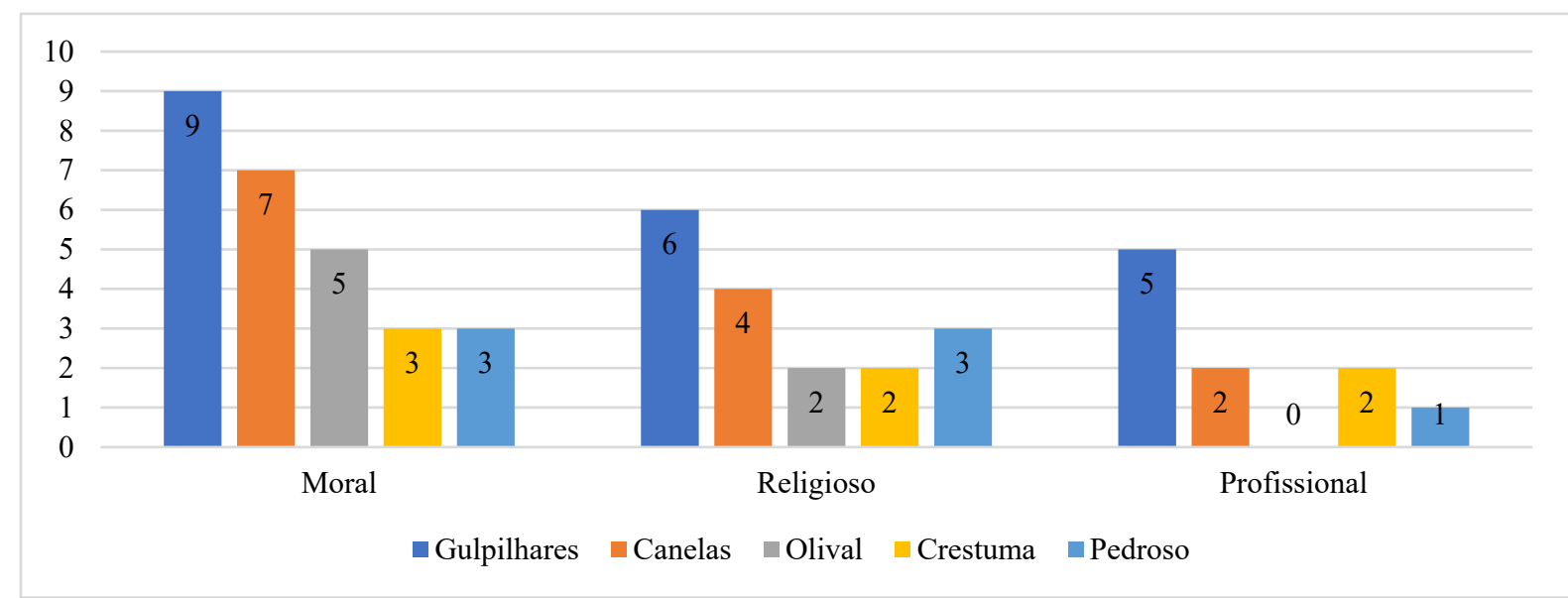

FONTE: Visitações de Gulpilhares. Ed. de Francisco Barbosa da Costa e João de Sousa. Vila Nova de Gaia: Câmara Municipal de Vila Nova de Gaia. Gabinete de História e Arqueologia, 1986; COSTA, Francisco Barbosa da - S. Pedro de Pedroso nos séculos XVIII e XIX.

Câmara Municipal de Vila Nova de Gaia. Junta de Freguesia de Pedroso, 2000; Títulos da Vezita q pertence ao Deado do PortoPT/ADPRT/DIO/CABIDO-01/1693, K/15/6/1 - 1693 (Arquivo Distrital do Porto).

No que concerne à natureza dos desvios, podemos destacar os de natureza moral como os mais praticados nas cinco paróquias dentro da cronologia estabelecida. Entre eles encontramse referências a práticas de "mulheres de maus costumes e má vida" 64 ou "pessoas com conversas escandalosas" ${ }^{65}$.

Seguem-se os de natureza religiosa e profissional em paróquias como Gulpilhares e Canelas com valores elevados. "Não rezam a missa na capela"66; "Proibir de trabalhar os moleiros aos dias santos e festas" ${ }^{97}$ são alguns dos títulos que se encontram.

Pedroso apresenta uma tendência que abarca as três tipologias, mas em números mais baixos. O quadro geral destes dados remete-nos para o domínio religioso e moral como alvos mais identificados nas ações desviantes dos fiéis. Logo, a postura da Igreja seria mais ativa face ao controlo destas condutas em sociedade.

\footnotetext{
${ }^{63}$ Ver SANTOS, Eugénio dos - "Os livros das visitas pastorais da região portuense: questões e perspectivas de abordagem”... pp. 237-244; CARVALHO, Joaquim Ramos de - Comportamentos morais e estruturas sociais numa paróquia de antigo regime...; e SILVA, Lisbeth Marilin Santos da - As visitas pastorais na diocese do Porto: (1675-1800): os comportamentos desviantes censurados...

${ }^{64}$ Títulos da Vezita q pertence ao Deado do Porto... 1776, fólio 80

${ }^{65}$ COSTA, Francisco Barbosa da - S. João Baptista de Canelas - notas monográficas... 1655.

${ }^{66}$ COSTA, Francisco Barbosa da - "Visitações da Igreja de Santa Maria de Olival, século XVIII"... 1754.

${ }^{67}$ Títulos da Vezita q pertence ao Deado do Porto... 1694, fólio 102.
} 
Face às ações dos crentes, conseguimos destacar a predominância da ação de denúncia como sendo a que mais suscita a intervenção do visitador. Desde Gulpilhares a Pedroso, os registos remetem-nos para a tipologia de denúncia, presente nas ações dos crentes na comunidade. Esta medida parece sustentar o que a bibliografia vai discutindo sobre esta matéria ${ }^{68}$. Através do cruzamento dos livros de visitas e as constituições diocesanas é possível compreender as diretrizes da Igreja que encaminham os crentes a denunciarem os "pecadores públicos" 69.

\section{Gráfico 3 - Tipologia das ações dos crentes.}

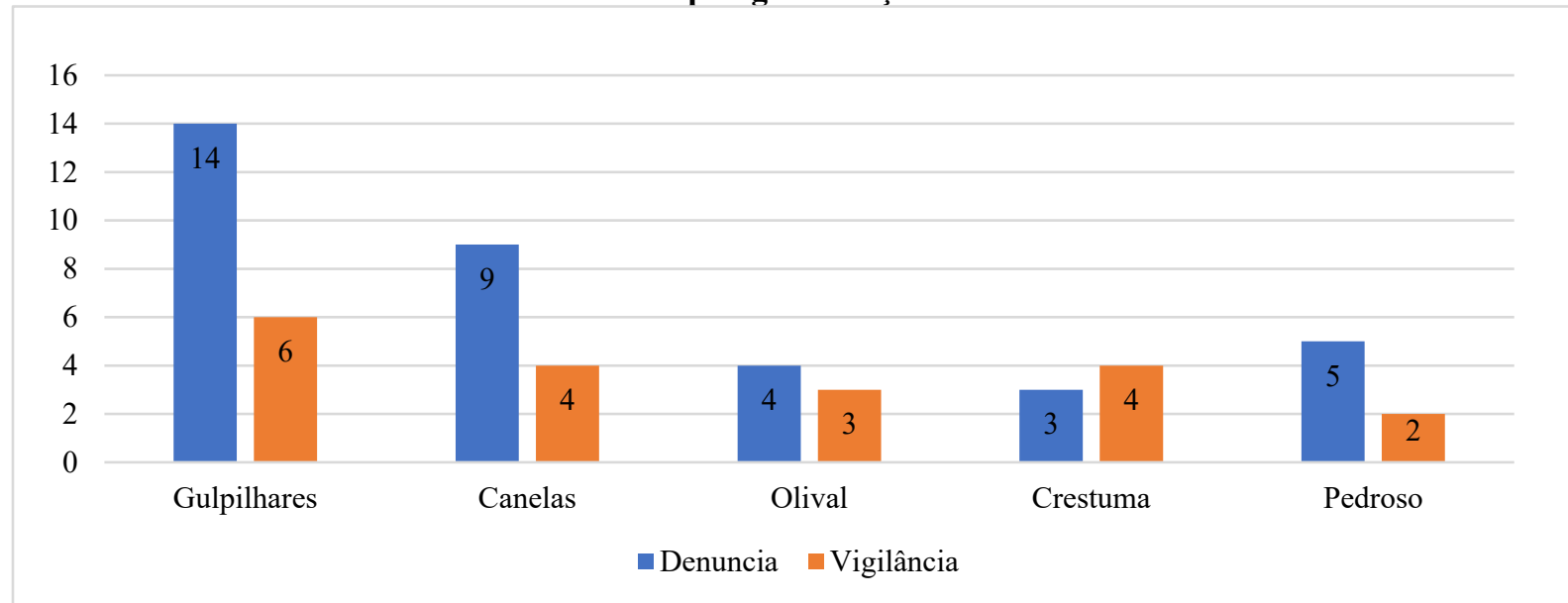

FONTE: Visitações de Gulpilhares. Ed. de Francisco Barbosa da Costa e João de Sousa. Vila Nova de Gaia: Câmara Municipal de Vila Nova de Gaia. Gabinete de História e Arqueologia, 1986; COSTA, Francisco Barbosa da - S. Pedro de Pedroso nos séculos XVIII e XIX.

Câmara Municipal de Vila Nova de Gaia. Junta de Freguesia de Pedroso, 2000; Titluos da Vezita q pertence ao Deado do PortoPT/ADPRT/DIO/CABIDO-01/1693, K/15/6/1 - 1693(Arquivo Distrital do Porto)

Ressumam do Gráfico 3 níveis de denúncia mais elevados em Gulpilhares e Canelas, tendo em conta as limitações da fonte. De modo geral, destacam-se as ações de denúncia e desvios morais e religiosos face a Pedroso, Olival e Crestuma. O cuidado em combater as bruxarias e superstições, práticas identificadas em algumas ações dos crentes, está patente nas constituições diocesanas $^{70 "}$. Deste modo, voltamos a reforçar a ideia de que dois séculos após a ação Tridentina, estes costumes profanos são combatidos nestas comunidades, por parte da Igreja, com fins e objetivos muito claros para com os "pecadores"71.

\footnotetext{
${ }^{68}$ Ver CARVALHO, Joaquim Ramos de - Comportamentos morais e estruturas sociais numa paróquia de antigo regime...; e SILVA, Lisbeth Marilin Santos da - As visitas pastorais na diocese do Porto: (1675- 1800): os comportamentos desviantes censurados...

${ }^{69}$ Ver PAIVA, José Pedro; CARVALHO, Joaquim - "A evolução das visitas pastorais da diocese de Coimbra nos séculos XVII e XVIII”... pp. 29-41; e CARVALHO, Joaquim Ramos de - Comportamentos morais e estruturas sociais numa paróquia de antigo regime...

${ }^{70}$ Assim acontece com o previsto no Livro 5 das Constituições Diocesanas do bispado de D. João de Sousa. Sobre esta matéria veja-se SOUSA, João de - Constituições sinodais do bispado do Porto...

${ }^{71}$ CARVALHO, Joaquim Ramos de - “A jurisdição episcopal sobre leigos em matéria de pecados públicos: as visitas pastorais e o comportamento moral das populações portuguesas de Antigo Regime". Revista Portuguesa de História. [Em Linha] Coimbra: FLUC. Instituto de História Económica e Social. Tomo 24 (1988) pp. 121-163.
} 


\subsection{Os espaços de sociabilidade}

Através dos registos dos livros de visitas conseguimos identificar alguns dos locais onde estes crentes convivam e interagiam, no seu quotidiano. Estes estão projetados no Gráfico 4, como resultado do levantamento da fonte em questão.

\section{Gráfico 4 - Espaços de Sociabilidade.}

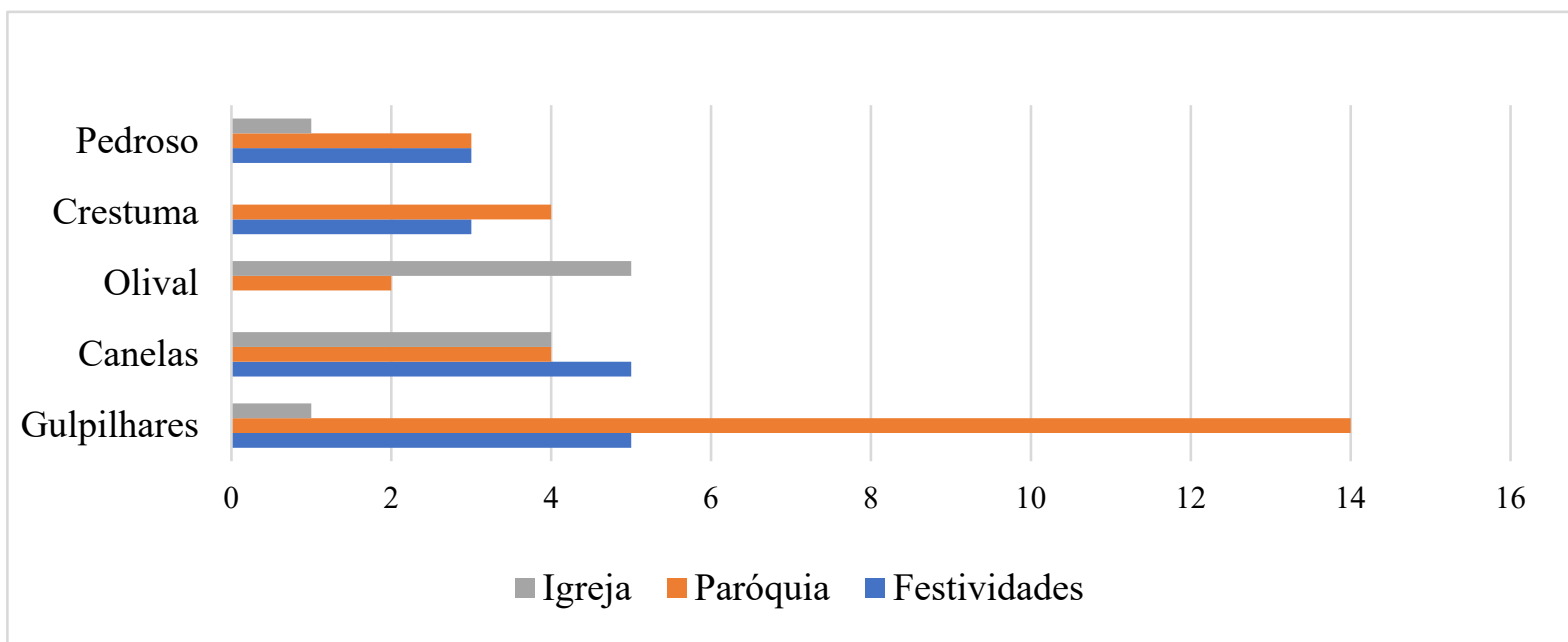

FONTE: Visitações de Gulpilhares. Ed. de Francisco Barbosa da Costa e João de Sousa. Vila Nova de Gaia: Câmara Municipal de Vila Nova de Gaia. Gabinete de História e Arqueologia, 1986; COSTA, Francisco Barbosa da - S. Pedro de Pedroso nos séculos XVIII e XIX.

Câmara Municipal de Vila Nova de Gaia. Junta de Freguesia de Pedroso, 2000; Titluos da Vezita q pertence ao Deado do PortoPT/ADPRT/DIO/CABIDO-01/1693, K/15/6/1 - 1693(Arquivo Distrital do Porto)

Ao observamos o gráfico constatamos a presença de três espaços distintos predominantes. A igreja, que abarca o espaço dentro da própria instituição; a paróquia como circunscrição mais abrangente para os crentes e as suas ações e por fim, as festividades, que inserem o profano e sagrando, ou seja, romarias e procissões.

Através das fontes em análise, conseguimos confirmar as leituras de alguns autores que apresentam estes espaços e as suas atividades como lugares de cruzamento entre o profano e sagrado, como ocorre, por exemplo com a multa de 1000 réis prevista para as "Pessoas bebem a água benta da igreja" ${ }^{\text {72 }}$.

Gulpilhares destaca-se a par de Canelas, pela preponderância de ações, e movimentações dos crentes em espaços públicos e as festividades. Vejam-se os títulos; "Mulheres solteiras nos serões"73 ou "Não durmam as mulheres de noite nos moinhos"74

Olival, Crestuma e Pedroso têm registadas predominantes práticas de sociabilidade relacionadas também com comportamentos em espaços públicos. Destaque-se o caso de Olival:

72 COSTA, Francisco Barbosa da - S. João Baptista de Canelas - notas monográficas... 1661.

73 Ibidem, 1686.

${ }^{74}$ Títulos da Vezita q pertence ao Deado do Porto... 1699, Fólio 107. 
"Mulheres do lugar de Arnelas iam lavar-se à fonte estando descompostas causando grande escândalo"75; "Mulheres em Arnelas vão ouvir missa a outra capela e não vão à igreja ouvir os preceitos da missa"76.

De modo geral, podemos constatar que a paróquia parece ser um dos grandes espaços de sociabilidade e de interação entre crentes, párocos e visitadores. Tal afirmação é sustentada por esta amostra. Entre 1607 e 1794 o levantamento de dados confirma que a paróquia é considerada como um local de pertença destas comunidades.

Quanto a práticas sociais relacionadas com festividades, estas tanto ocorrem no espaço da igreja como em espaços de festividades laicas, estas por vezes associadas a romarias e a procissões ${ }^{77}$. Práticas como "desordem nas vendas por causa dos jogos"78; "padres mascarados nas festas"79 são disso elucidativos. São estes os espaços onde todos os crentes convivem e sociabilizam no Antigo Regime- entre espaços "sagrados e profanos" 80.

Tendo em conta o espectro e variáveis de análise utilizadas, assim como as fontes cruzadas, compreendemos que a prática do jogo, a venda de vinho ou as folias nas festas, são consideradas desviantes, pela ação do Bispo e da Igreja ${ }^{81}$. Isto em nada contraria as tendências apontadas pela historiografia.

\subsection{Ação da Igreja: o Visitador}

A análise da ação do bispo visitador tem sido trabalhada por diversos autores, que vão focando o perfil destes bispos e os percursos enquanto fiscalizadores da ação pastoral.

José Pedro Paiva ${ }^{82}$ e Lisbeth Santos da Silva ${ }^{83}$ são alguns dos autores que se focaram nesta perspetiva de estudo, com áreas distintas de abordagem e universos distintos de análise. Referem-se ao perfil destes eclesiásticos, formação, percurso e atuação em universos distintos.

Nesta abordagem, o intuito da análise não será o perfil do visitador, o seu percurso ou suas redes, mas a sua ação face aos comportamentos dos fiéis registados nos livros de visitas, em primeiro plano. Em segundo plano, pretende-se verificar se ação do visitador corresponde à norma ou diretriz emitida pela Igreja Católica, coligida nas constituições diocesanas.

\footnotetext{
${ }^{75}$ Títulos da Vezita q pertence ao Deado do Porto... 1700.

${ }^{76}$ Títulos da Vezita q pertence ao Deado do Porto... 1706.

${ }^{77}$ KAMEN, Henry - Early modern European society. 2. ${ }^{\text {a }}$ ed. revista. Londres: Routledge, 2005. pp. 173-175.

${ }^{78}$ Títulos da Vezita q pertence ao Deado do Porto... 1772.

${ }^{79}$ Visitações de Gulpilhares... 1675, Fólio 76.

${ }^{80}$ CATARINO, Maria Manuela - Entre o Sagrado e o Profano... (para uma leitura do Livro de Visitações da freguesia de S.Pedro da Cadeira - sécs. XVII e XVIII). In SILVA, Carlos Guardado da (coord.) - Turres Veteras X, História do Sagrado e do Profano. Lisboa: Edições Colibri [etc.], 2008. pp. 225-230.

${ }^{81}$ Presentes nos Livros de Visitas de Gulpilhares, Olival, Pedroso, Canelas e Crestuma.

${ }^{82}$ PAIVA, José, Pedro - “Os bispos e a Inquisição portuguesa (1536-1613)”... pp. 43-76.

${ }^{83}$ SILVA, Lisbeth Marilin Santos da - As visitas pastorais na diocese do Porto: (1675-1800): os comportamentos desviantes censurados...
} 
Neste sentido, este cruzamento de dados visa responder a algumas questões, entre as quais: A vida comunitária seria pautada pelos livros de visitações como mecanismos de controlo? O que era imposto pelas visitações seria na realidade cumprido? Os gráficos aqui apresentados são uma amostragem de 54 registos de ações de visitadores em visitas distintas às 5 paróquias escolhidas como universo de estudo, ou seja, tomando em bloco os cinco livros de visitas como fonte das informações.

O segundo momento será cruzar esses dados com o conjunto de registos normativos que foram retirados das constituições diocesanas, tecendo algumas considerações. No que concerne ao Gráfico 5 podemos retirar alguns dados que dizem respeito à ação do visitador sobre os comportamentos dos crentes, tendo-se classificado a sua ação como preventiva ou punitiva.

Gráfico 5 - Ação do Visitador nos Livros de Visitas - 1607-1794.

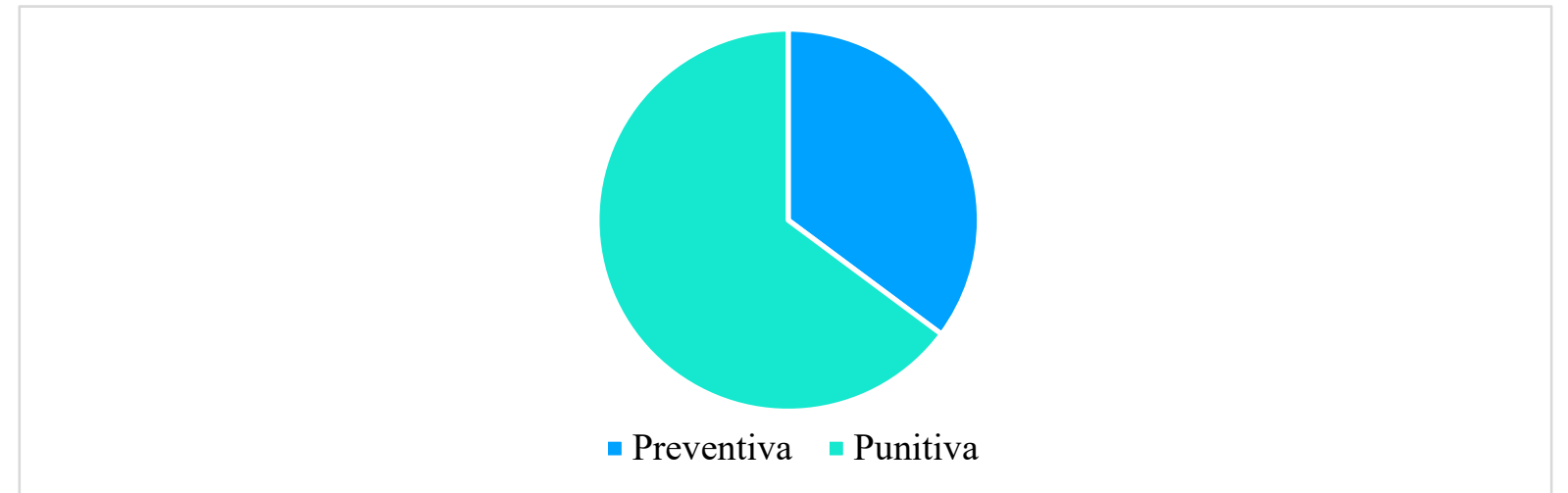

FONTES: Visitações de Gulpilhares. Ed. de Francisco Barbosa da Costa e João de Sousa. Vila Nova de Gaia: Câmara Municipal de Vila Nova de Gaia. Gabinete de História e Arqueologia, 1986; COSTA, Francisco Barbosa da - S. Pedro de Pedroso nos séculos XVIII e XIX. Câmara Municipal de Vila Nova de Gaia. Junta de Freguesia de Pedroso, 2000; Titluos da Vezita q pertence ao Deado do PortoPT/ADPRT/DIO/CABIDO-01/1693, K/15/6/1 - 1693(Arquivo Distrital do Porto)

Face aos comportamentos analisados até agora, a ação do bispo será maioritariamente punitiva. Esta medida pode constatar-se ao longo dos vários registos nos livros de vistas.

Essa intervenção punitiva revela que a instituição Igreja escolhe impor as suas normas de conduta com base em castigos que disciplinem estas comunidades, depreendendo-se a convicção de que uma intervenção nas sociabilidades destes fiéis seria mais efetiva do que a ação preventiva.

O Bispo visitador funciona como um ator corretivo. Mais do que impor a sua vontade, tem de implementar as estratégias de disciplinamento social da Igreja para incentivar a adoção dos valores e crenças, do mundo católico, nos crentes. Essa relação está presente no quadro 1, que contempla a ação do visitador sobre os desvios dos crentes face ao estipulado nas Constituições Diocesanas. 
Esta leitura pode ser aprofundada com o cruzamento com o Gráfico 6, que demonstra que as constituições consagram uma atitude mais preventiva do que punitiva, para o clero, verificando-se o contrário no que se refere aos crentes. Nele observamos uma preponderância de diretivas que visam o clero, presente no levantamento de dados nas constituições, o que demonstra uma clara preocupação face aos seus comportamentos e ações, enquanto guia pastoral da comunidade paroquial.

\section{Gráfico 6 - Agentes visados nas constituições diocesanas.}

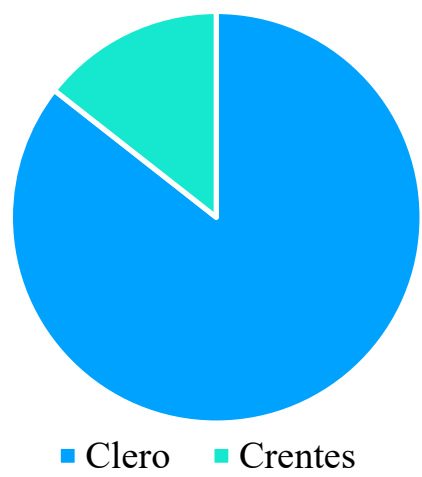

FONTES: SOUSA, João de - Constituições sinodais do bispado do Porto. Coimbra: Real Collegio das Artes da Companhia de Jesus, 1735.

Em finais do século XVIII presenciamos um contínuo desleixo do clero paroquial face às suas funções ${ }^{84}$. Ao longo do trabalho também nos podemos socorrer de relatos decorrentes das leituras da historiografia para confirmar esta afirmação ${ }^{85}$.

De igual modo, é possível visualizar esta "crise da paróquia" nos registos utilizados pela abordagem deste trabalho ${ }^{86}$. As chamadas de atenção que identificamos nas constituições diocesanas e nos livros de visita face à ausência dos párocos na paróquia, ou o não cumprimento das suas funções enquanto pastores evidenciam-no.

A atenção sobre os crentes era de igual modo importante. Contudo, a preocupação com a formação do clero poderia ser um caminho mais seguro para controlar e transmitir as ideias da igreja às massas dos crentes ${ }^{87}$.

\footnotetext{
84 “O padre não quer acompanhar os fiéis na procissão", diz-se no Livro de Visitas de Gulpilhares de 1617. Ver Visitações de Gulpilhares...

${ }^{85}$ CAPELA, José Viriato - A crise da paróquia no Antigo Regime: a paróquia rural portuguesa a caminho de um novo modelo de ação paroquial. Nova pastoral. Ensino e assistência. In ARAÚJO, Maria Marta Lobo de; ESTEVES, Alexandra (eds) - Marginalidade, Pobreza e Respostas Sociais na Peninsula Ibérica, séculos XVI-XX. [Em Linha] Braga: CITCEM, 2011. p. 89-105.

${ }^{86}$ Ibidem.

${ }^{87}$ SILVA, Francisco Ribeiro da - "O Bispado do Porto à luz das constituições sinodais da época moderna: valores clericais e normas de comportamento."... pp. 57-81.
} 


\section{Gráfico 7 - Normas Diocesanas}

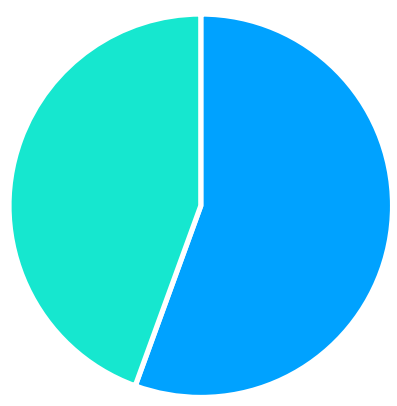

- Preventiva $=$ Punitiva

FONTES: SOUSA, João de - Constituições sinodais do bispado do Porto. Coimbra: Real Collegio das Artes da Companhia de Jesus, 1735.

O Gráfico 7 projeta dados referentes às constituições diocesanas. Aqui, e como ficou dito, as ações de caráter preventivo predominam face às punitivas. O que é natural, uma vez que são normas de orientação de comportamentos, ao contrário da incidência das visitações, que visam corrigir desvios e práticas não consonantes com o estipulado, também nas Constituições.

Tanto os bispos como o clero local deveriam obedecer a todo um processo e divulgação da visita, e tinham um conjunto de "chamadas de atenção" para vários comportamentos contrários à conduta católica ${ }^{88}$.

Os estudos de José Pedro Paiva e Lisbeth Santos da Silva remetem para a importância que certos bispos atribuem ao clero e à sua ação durante o processo de visitação. No caso do Porto, podemos destacar que as ações sobre o clero paroquial foram de suma importância para o bispo regente ${ }^{89}$, assim como todo o processo de devassa era maioritariamente voltado para as ações dos crentes, mas nunca perdendo de vista a figura e a atuação do pároco local ${ }^{90}$.

Este confronto entre norma e desvio em ações de crentes ou clérigos encontra-se documentada no quadro 1, que compreende, na componente das Visitações, as cinco paróquias, entre os séculos XVII e XVIII. Através deste cruzamento conseguimos comprovar a preocupação de punição presente nas visitações e a norma diretiva presente nas constituições ${ }^{91}$.

Na paróquia de Gulpilhares, é registado, no livro de vistas de 1626 que "Mulheres de maus costumes e desonestas" estavam a perturbar a boa conduta desta região. Esta ação dos crentes é punida pelo bispo visitador e também prevista nas constituições, sob o artigo "punir palavras escandalosos e ofensas a deus" ${ }^{92}$.

\footnotetext{
${ }^{88}$ SOUSA, João de - Constituições sinodais do bispado do Porto...

${ }^{89}$ SILVA, Lisbeth Marilin Santos da - As visitas pastorais na diocese do Porto: (1675- 1800): os comportamentos desviantes censurados...

${ }^{90}$ CARVALHO, Joaquim Ramos de - Comportamentos morais e estruturas sociais numa paróquia de antigo regime...

${ }^{91}$ PAIVA, José Pedro - “Inquisição e visitas pastorais: dois mecanismos complementares de controle social?". Revista de História das Ideias. [Em Linha] Coimbra: Imprensa da Universidade de Coimbra. Vol. 11 (1989) pp. 85-102.

92 Visitações de Gulpilhares...
} 
Este cruzamento entre a norma diocesana versus a ação do visitador como linha de análise, permite constatar que as várias ações do bispo visitador acabavam, no fundo, por refletir as inquietações e conceitos que a Igreja Católica pretendia pregar através da pastoral, as quais se encontram expressas nas Constituições diocesanas. Esta convergência era, na verdade, desejável e o seu efeito esperado pelos decretos tridentinos.

A vida comunitária tendia a ser pautada por estas normas, porém as sucessivas denúncias das ações dos crentes, ou a ação do Bispo sobre estes fiéis refletem que estas comunidades fugiam ao que era na realidade, imposto pela Igreja, de forma normativa e punitiva. Por um lado, a Igreja incentiva, através do bispo visitador e da formação do clero local, a denúncia destes desvios. Mas por outro lado, as ações dos crentes refletem, na sua espontaneidade, um leque de práticas de sociabilidade ancestrais e adquiridos, dificilmente colmatado, mesmo num espaço secular, pela normatividade de Trento ${ }^{93}$.

Os livros de visitas tornam-se, pois, fontes indispensáveis à ação pastoral, por um lado para recolher informações e fazer diagnósticos sobre o seu bispado, e por outro lado para aferir se as suas indicações eram, de facto cumpridas ${ }^{94}$.

\section{Considerações Finais}

O que se apresentou no presente trabalho permite sustentar e documentar a afirmação de Gabriel Le Bras, segundo a qual a paróquia é um "mundo vivo; uma pessoa jurídica e um ser histórico". Através do estudo das paróquias conseguimos observar a "coletividade dos seus habitantes, um povo com unidade de costumes; são agentes de estatuo no fim espiritual e esboçam várias realidades e evoluções das comunidades que as rodeiam" 95 .

No domínio do disciplinamento social constatamos que a igreja de forma direta e indireta utiliza mecanismos como os livros de visitas e os visitadores, para fazer cumprir as diretrizes católicas patentes nas normas diocesanas, direcionadas para leigos e eclesiásticos ${ }^{96}$. A dimensão moral e religiosa demonstra-se de profunda relevância para estas sociedades de

\footnotetext{
${ }^{93}$ Essas práticas são, porém, identificados como "pecados públicos" segundo Joaquim Ramos de Carvalho, e por isso punidos. CARVALHO, Joaquim Ramos de - "A jurisdição episcopal sobre leigos em matéria de pecados públicos... pp. 161-163.

${ }^{94}$ SANTOS, Eugénio dos - "Os livros das visitas pastorais da região portuense: questões e perspectivas de abordagem"... pp. 237-244.

${ }^{95}$ LE BRAS, Gabriel - Études de sociologie religieuse. Paris: Presses Universitaires de France, 1955-1956. 2 vols..

${ }^{96}$ PAIVA, José Pedro - “Inquisição e visitas pastorais: dois mecanismos complementares de controle social?”... pp. 85-102.
} 
Antigo Regime que se encontram umbilicalmente ligadas à paróquia e à instituição igreja que, por sua vez, pautam a vida em sociedade ${ }^{97}$.

Assim, ao atentar-mos nestes "universos de estudo" verificamos o forte cunho tridentino não só através dos dados retirados das fontes, mas também ao confrontar-mos as ações diárias dos "fregueses" de cada paróquia. O nosso estudo aponta para uma forte vigilância, por parte do mundo católico relativamente aos seus fiéis, mas também um conjunto de hábitos e medidas, que visavam conter e denunciar comportamentos moralmente condenáveis aos olhos da igreja ${ }^{98}$.

Nas paróquias em análise, como em tantas outras da Cristandade Ocidental, e do mundo católico em particular, os crentes eram vigiados pela Igreja e os seus agentes, o pároco e o visitador, sendo os seus comportamentos alvo de suspeição e punição, como observamos. Sobre esses espaços onde interagiam, vivam e morriam os crentes, pouco se tem explorado com base nos livros de vistas. Esta dimensão de estudo social é sem dúvida, uma das mais complexas de abordar, até pela qualidade e quantidade das fontes disponíveis.

Na paróquia, as realidades da esfera social e religiosa acabam por se completar, como o comprovam os dados apresentados, sabendo que a esfera social é pela vivência coletiva de agentes que eram, sobretudo, crentes. A experiência individual do sagrado também é coletiva, como se constata nestes espaços de sociabilidade ${ }^{99}$.

A complementaridade de análise da História Religiosa e da História Social é por isso indispensável, não existindo sociedade sem religião, nem religião sem formas de sociabilidade $^{100}$. Esta foi o foco seguido neste trabalho, que se centrou também no esboço de uma análise que pretendeu acompanhar e testar perspetivas de análise já utilizadas por outros autores, mas com leituras aplicadas a outros estudos de caso.

Em futuras investigações poderemos explorar possíveis relações entre a história religiosa e a história das mulheres, na medida em que conseguimos retira algumas informações interessantes para definir o perfil deste "grupo das mulheres" nas comunidades de Antigo Regime e avaliar o seu papel enquanto atores sociais.

Por último, ainda que com limitações impostas pelas fontes e porventura pela incipiente experiência do autor, este trabalho conduziu-nos ao ritmo do quotidiano destas comunidades e

\footnotetext{
${ }^{97}$ Ver BETHENCOURT, Francisco - “As visitas pastorais: Um estudo de caso (Entradas, 1572-1593)”. Revista de História Económica e Social. I série. Vol. 19 (1987) pp. 95-112; e CARVALHO, Joaquim Ramos de Comportamentos morais e estruturas sociais numa paróquia de antigo regime...

${ }^{98}$ CARVALHO, Joaquim de - "Micro-Historical Perspectives on Moral Choice: Case Studies from Early Modern Portugal"... pp. 1-18.

CARVALHO, Joaquim Ramos de - “A jurisdição episcopal sobre leigos em matéria de pecados públicos...

99 GODINHO, Vitorino Magalhães - A História Social: Problemas, Fontes e Métodos...

${ }^{100}$ Ibidem.
} 
dos homens e mulheres comuns, nos seus efetivos espaços de interação. Esta perspetiva, incidente sobre os espaços que os crentes/ fregueses frequentavam numa base quotidiana poderá conduzir a futuros estudos que prossiga modelos já testados por outros autores sobre a recriação das redes de sociabilidade em comunidades de Antigo Regime ${ }^{101}$.

\section{Fontes}

\section{Fontes Manuscritas:}

Títulos da Vezita q pertence ao Deado do Porto - PT/ADPRT/DIO/CABIDO-01/1693, K/15/6/1 - 1693 (Arquivo Distrital do Porto).

\section{Fontes Impressas:}

Visitações de Gulpilhares. Ed. de Francisco Barbosa da Costa e João de Sousa. Vila Nova de Gaia: Câmara Municipal de Vila Nova de Gaia. Gabinete de História e Arqueologia, 1986. 255p.

O foral manuelino de Vila Nova de Gaya, 1518-2018. Ed. de Eduardo Vítor Rodrigues; Trad. Susana Guimarães; Transc. de Sónia Feirreia. Vila Nova de Gaia: Câmara Municipal de Vila Nova de Gaia, 2018. ISBN 978-972-581-078-1.

SOUSA, João de - Constituições sinodais do bispado do Porto. [Em Linha] Coimbra: Real Collegio das Artes da Companhia de Jesus, 1735. Disponível em WWW:<URL: http://hdl.handle.net/10316.2/9607>.

\section{Outras Fontes:}

COSTA, Francisco Barbosa da - "Usos e Costumes nos livros de visitações de algumas freguesias de Gaia”. Separata da Revista Gaia, vol. II. Vila Nova de Gaia: Gabinete de História e Arqueologia de Vila Nova de Gaia, 1984. pp. 281-290. 301 p..

- - S. João Baptista de Canelas - notas monográficas. Canelas: Edição da Paróquia de Canelas, 1980. 453 p.

- - S. Pedro de Pedroso nos séculos XVIII e XIX. Câmara Municipal de Vila Nova de Gaia. Junta de Freguesia de Pedroso, 2000. ISBN: 972-581-037-6.

- - "Visitações da Igreja de Santa Maria de Olival, século XVIII". Separata da Revista Gaia, vol. I. Vila Nova de Gaia: Gabinete de História e Arqueologia de Vila Nova de Gaia, 1983. 12 p..

\footnotetext{
${ }^{101}$ CARVALHO, Joaquim de - "Micro-Historical Perspectives on Moral Choice: Case Studies from Early Modern Portugal"... pp. 1-18.
} 


\section{Bibliografia}

ALMEIDA, Fortunato de - História da igreja em Portugal. Nova edição preparada e dirigida por Damião Peres. Porto: Portucalense Editora, 1967-1968. Vol. 1 e Vol. 2.

AZEVEDO, Carlos A. Moreira - Dicionário de história religiosa de Portugal. Lisboa: Círculo de Leitores, 2000-2001.

AZEVEDO, Carlos A. Moreira (dir.) - Humanismos e reformas, Vol. 2 de MARQUES, João Francisco, e GOUVEIA, António Camões (coord.). "História religiosa de Portugal". Lisboa: Círculo de Leitores, 2000-2002.

BETHENCOURT, Francisco - "As visitas pastorais: Um estudo de caso (Entradas, 15721593)”. Revista de História Económica e Social. I série. Vol. 19 (1987) pp. 95-112.

CAPELA, José Viriato - A crise da paróquia no Antigo Regime: a paróquia rural portuguesa a caminho de um novo modelo de ação paroquial. Nova pastoral. Ensino e assistência. In ARAÚJO, Maria Marta Lobo de; ESTEVES, Alexandra (eds) - Marginalidade, Pobreza e Respostas Sociais na Península Ibérica, séculos XVI-XX. [Em Linha] Braga: CITCEM, 2011. p. 89-105. Disponível em WWW:<URL: http://www.lasics.uminho.pt/ojs/index.php/citcem/article/view/634>.

CARVALHO, Joaquim de - "Micro-Historical Perspectives on Moral Choice: Case Studies from Early Modern Portugal”. E-Journal of Portuguese History. [Em Linha] Rhode Island, Porto: Brown University, Universidade do Porto. Vol.2, n. ${ }^{\circ} 2$ (2004) pp. 1-18. Disponível em WWW: $<$ URL:https://digitalis.uc.pt/ptpt/artigo/micro_historical_perspectives_moral_choices_case_studies_early modern_portugal $>$.

— - "A jurisdição episcopal sobre leigos em matéria de pecados públicos: as visitas pastorais e o comportamento moral das populações portuguesas de Antigo Regime". Revista Portuguesa de História. [Em Linha] Coimbra: FLUC. Instituto de História Económica e Social. Tomo 24 (1988) pp. 121-163. Disponível em WWW:<URL:http://hdl.handle.net/10316/12788>.

- - Comportamentos morais e estruturas sociais numa paróquia de antigo regime: Soure, 1680-1720: reconstituições, interpretações e metodologias. [Em Linha] Coimbra: Faculdade de Letras da Universidade de Coimbra, 1997. Dissertação de Doutoramento em História Moderna. Disponível em WWW:<URL:http://hdl.handle.net/10316/702>.

CARVALHO, Joaquim; PAIVA, José Pedro - "A evolução das visitas pastorais da Diocese de Coimbra nos séculos XVII e XVIII”. Ler História. [Em Linha] N. o 15 (1989) pp. 29-41. Disponível em WWW:<URL: https://www.academia.edu/34904584/A_evolu\%C3\%A7\%C3\%A3o_das visitas pasto rais da diocese de Coimbra nos_s\%C3\%A9culos_XVII_e XVIII with_Joaquim_R amos de Carvalho_>.

CATARINO, Maria Manuela - Entre o Sagrado e o Profano... (para uma leitura do Livro de Visitações da freguesia de S.Pedro da Cadeira - sécs. XVII e XVIII). In SILVA, Carlos 
Guardado da (coord.) - Turres Veteras X, História do Sagrado e do Profano. Lisboa: Edições Colibri [etc.], 2008. pp. 225-230.

GODINHO, Vitorino Magalhães - A História Social: Problemas, Fontes e Métodos. Colóquio da Escola Normal Superior de Saint-Cloud (15-16 de Maio de 1965). Trad. Maria Antonieta Magalhães Godinho. Lisboa: Edições Cosmos, 1973.

KAMEN, Henry - Early modern European society. 2. ${ }^{\text {e }}$ ed. revista. Londres: Routledge, 2005.

LE BRAS, Gabriel - Études de sociologie religieuse. Paris: Presses Universitaires de France, 1955-1956. 2 vols..

MARQUES, A. H. de Oliveira; SERRÃO, Joel (dir.) - Portugal do renascimento à crise dinástica. Vol. 5 de DIAS, João Alves (coord.), "Nova História de Portugal”. Lisboa: Editorial Presença, 1998.

MATTOSO, José (dir.) - No Alvorecer da Modernidade (1480-1620), Vol. 3 de MAGALHÃES, Joaquim Romero (coord.), "História de Portugal". Lisboa: Editorial Estampa, 1997.

NETO, Margarida Sobral - "Historiografia Portuguesa da Época Moderna". Revista de Teoria da História, vol. 17. 2017, pp. 124-146.

- - "Senhorios e concelhos na época moderna: relações entre dois poderes concorrentes". In CUNHA, Mafalda Soares da; FONSECA, Teresa, (eds.) - Os Municípios no Portugal Moderno: Dos Forais Manuelinos às Reformas Liberais. [Em Linha] Lisboa: Edições Colibri, CIDEHUS-UE, 2005. pp. 149-165. Disponível em: WWW:<URL:http://hdl.handle.net/10316/86341>.

PAIVA, José Pedro - "Pastoral Visitations in the First World Empires (Spain and Portugal in the 16th and 17th Centuries): A Comparative Approach." [Em linha]. Journal of Early Modern History. Vol. 24, n. ${ }^{\circ}$ 3. pp. 224-252. Disponível em: WWW:<URL: https://doi.org/10.1163/15700658-12342670>.

— - "Inquisição e visitas pastorais: dois mecanismos complementares de controle social?". Revista de História das Ideias. [Em Linha] Coimbra: Imprensa da Universidade de Coimbra. ISSN: 2183-8925. Vol. 11 (1989) pp. 85-102. Disponível em: WWW: <URL:http://hdl.handle.net/10316.2/42911>.

- - Bruxaria e superstição num país sem "caça às bruxas": 1600-1774. 2. ed. Lisboa: Editorial Notícias, 2002.

_ - “Os bispos e a Inquisição portuguesa (1536-1613)". Lusitania Sacra. [Em Linha] Lisboa: Centro de Estudos de História Religiosa - Universidade Católica Portuguesa. 2. ${ }^{a}$ Série, Tomo 15, (2003) pp. 43-76. Disponível em: WWW:<URL: http://hdl.handle.net/10400.14/4407>.

PENTEADO, Pedro - "Confrarias portuguesas da época moderna: problemas, resultados e tendências da investigação”. Lusitania Sacra. CEHR, 1995, pp.15-52. 
PEREIRA, Isaías da Rosa - "Visitas Paróquias dos Séculos XIV, XV e XVI". Lusitania Sacra. $2^{\mathrm{a}}$ série, Tomo IV (1992) pp. 311-344. Disponível em: WWW:<URL: https://doi.org/10.34632/lusitaniasacra.1993.8045>.

POLÓNIA, Amélia - “A recepção do Concílio de Trento em Portugal”. In GOUVEIA, António Camões; BARBOSA, David Sampaio; PAIVA, José Pedro (coord.) - O Concílio de Trento em Portugal e nas suas conquistas: olhares novos. Lisboa: Universidade Católica Portuguesa. Centro de Estudos de História Religiosa, 2014.

RAMOS, Luís António Oliveira de - História do Porto. Porto: Porto Editora, 2000.

SANTOS, Cândido Augusto Dias dos - "Gaia do século XVI ao século XVIII: História Económica e Social”. In AA. VV. - História de Gaia. Vila Nova de Gaia: Câmara de Vila Nova de Gaia, 1985. pp. 321-438.

SANTOS, Eugénio dos - "Os livros das visitas pastorais da região portuense: questões e perspectivas de abordagem". Revista de História. [Em Linha] Porto: Universidade do Porto. Faculdade de Letras. N. 2 (1979) pp. 237-244. Disponível em WWW:<URL: http://hdl.handle.net/10216/13170>.

SILVA, Francisco Ribeiro da - "O Bispado do Porto à luz das constituições sinodais da época moderna: valores clericais e normas de comportamento." In Tempos e lugares de memória: homenagem a D. Domingos de Pinho Brandão. Actas Vol.1. [Em Linha] Aveiro: Centro de Estudos D. Domingos de Pinho Brandão [etc.]: 2002. pp. 57-81. Disponível em WWW:<URL:https://hdl.handle.net/10216/54027>.

- - O Porto e o seu termo 1580-1640: Os homens as instituições e o poder. Volume I. Porto: [Edição do Autor], 1985.

SILVA, Lisbeth Marilin Santos da - As visitas pastorais na diocese do Porto: (1675- 1800): os comportamentos desviantes censurados. [Em Linha] Porto: [Edição de Autor], 2007. Dissertação de Mestrado. Disponível em WWW:<URL: http://hdl.handle.net/10216/14676>.

SOARES, A. Franquelim S. Neiva - “A sociedade do antigo regime nas visitações e inquéritos paroquiais do distrito de Braga: I - Abação (S. Cristóvão)". Revista Theologica. Vol. 13 (1979) pp. 429-565.

SOARES, António Franquelim Sampaio Neiva - A arquidiocese de Braga no séc. XVII: sociedade e mentalidades pelas visitações pastorais (1550-1700). Braga: [Edição de Autor], 1993.

VALE, Carlos - A Freguesia de Santa Maria de Gulpilhares. Vila Nova de Gaia: Junta de Freguesia. 1987. 


\section{Anexos}

Quadro 1 - Constituições versus Visitações: Ações que visam Clérigos e Crentes.

\begin{tabular}{|c|c|c|c|c|}
\hline Data & Ação dos Crentes & $\begin{array}{l}\text { Articulado das } \\
\text { Constituições }\end{array}$ & Capítulo de Visitas & Paróquia \\
\hline 1626 & $\begin{array}{l}\text { Mulheres de maus } \\
\text { costumes e } \\
\text { desonestas }\end{array}$ & $\begin{array}{c}\text { punir palavras } \\
\text { escandalosas e ofensas }\end{array}$ & $\begin{array}{l}\text { Punir as mulheres com } \\
\text { palavras escandalosas }\end{array}$ & Gulpilhares \\
\hline 1661 & $\begin{array}{l}\text { Fregueses não bebam } \\
\text { a água benta da igreja }\end{array}$ & $\begin{array}{l}\text { Denúncia palavras ou } \\
\text { superstições }\end{array}$ & Pena de mil reis & Canelas \\
\hline 1675 & $\begin{array}{l}\text { Ação de Sacerdotes } \\
\text { com armas }\end{array}$ & Multa e castigado & Punir os que usam armas & Gulpilhares \\
\hline 1676 & $\begin{array}{l}\text { Parteiras não } \\
\text { batizavam }\end{array}$ & Vigiar certas profissões & Examinar parteiras e batizar & Gulpilhares \\
\hline 1694 & $\begin{array}{l}\text { Pessoas maliciosas } \\
\text { bebem água de Igreja }\end{array}$ & $\begin{array}{l}\text { Denúncia palavras ou } \\
\text { superstições }\end{array}$ & Pena de Excomunhão & Canelas \\
\hline 1694 & $\begin{array}{l}\text { Moleiros não } \\
\text { guardam os dias } \\
\text { santos }\end{array}$ & $\begin{array}{l}\text { Guardar domingos, dias } \\
\text { santos e festas do ano }\end{array}$ & $\begin{array}{l}\text { Proibir moleiros de trabalhar } \\
\text { aos dias santos }\end{array}$ & Gulpilhares \\
\hline 1700 & $\begin{array}{c}\text { Mulheres } \\
\text { descompostas na } \\
\text { fonte e causam } \\
\text { distúrbios com os } \\
\text { homens a ver }\end{array}$ & $\begin{array}{l}\text { Observem o modo de vida } \\
\text { das pessoas e estrangeiros }\end{array}$ & $\begin{array}{l}\text { Denunciar casos } \\
\text { escandalosos }\end{array}$ & Olival \\
\hline 1706 & $\begin{array}{l}\text { Mulheres vão ouvir } \\
\text { missa a outra capela }\end{array}$ & $\begin{array}{l}\text { Celebrar a missa nas } \\
\text { igrejas e fregueses ouvem }\end{array}$ & $\begin{array}{l}\text { Não se sabe ao certo a } \\
\text { capela, devem ouvir missa } \\
\text { na capela do pároco }\end{array}$ & Olival \\
\hline 1727 & $\begin{array}{c}\text { Moleiros não } \\
\text { guardavam domingos } \\
\text { nem dias santos }\end{array}$ & $\begin{array}{l}\text { Guardar domingos, dias } \\
\text { santos e festas do ano }\end{array}$ & $\begin{array}{l}\text { Proibir moleiros de trabalhar } \\
\text { aos dias santos }\end{array}$ & Crestuma \\
\hline 1731 & $\begin{array}{l}\text { Mulheres } \\
\text { descompostas na } \\
\text { procissão }\end{array}$ & $\begin{array}{c}\text { Evitar abusos em } \\
\text { procissões - rir, costumes } \\
\text { indecentes }\end{array}$ & $\begin{array}{l}\text { Punir os homens e mulheres } \\
\text { em atos indecentes }\end{array}$ & Canelas \\
\hline 1772 & $\begin{array}{c}\text { Nomear dois homens } \\
\text { para vigiar quem } \\
\text { trabalha }\end{array}$ & $\begin{array}{l}\text { Guardar domingos, dias } \\
\text { santos e festas do ano }\end{array}$ & $\begin{array}{l}\text { Vigiar quem trabalha aos } \\
\text { dias santos }\end{array}$ & Crestuma \\
\hline 1780 & $\begin{array}{l}\text { Mulheres misturam- } \\
\text { se com os homens na } \\
\text { igreja }\end{array}$ & $\begin{array}{c}\text { Como os leigos assistem } \\
\text { às missas }\end{array}$ & $\begin{array}{c}50 \text { reis de multa para as } \\
\text { mulheres que ultrapassem as } \\
\text { grades da igreja- separando- } \\
\text { as dos homens }\end{array}$ & Olival \\
\hline 1782 & $\begin{array}{l}\text { Ofensas a Deus nas } \\
\text { romarias }\end{array}$ & Julgado pelos seus atos & $\begin{array}{l}\text { Punir quem o fizer em } \\
\text { romarias, os foliões }\end{array}$ & Pedroso \\
\hline 1794 & Denunciar pecadores & $\begin{array}{c}\text { Denunciar e descobrir os } \\
\text { hereges }\end{array}$ & $\begin{array}{c}\text { Denunciar nas visitações e } \\
\text { juiz eclesiástico }\end{array}$ & Pedroso \\
\hline 1794 & $\begin{array}{l}\text { Excomunhão aos } \\
\text { eclesiásticos em festa }\end{array}$ & $\begin{array}{l}\text { Padres não participem em } \\
\text { festas, jogos, folias }\end{array}$ & $\begin{array}{c}\text { Não deixar os clérigos } \\
\text { assistirem a festas pagas- } \\
\text { denunciar }\end{array}$ & Pedroso \\
\hline
\end{tabular}

FONTES: SOUSA, João de - Constituições sinodais do bispado do Porto. [Em Linha] Coimbra: Real Collegio das Artes da Companhia de Jesus, 1735; Visitações de Gulpilhares. Ed. de Francisco Barbosa da Costa e João de Sousa. Vila Nova de Gaia: Câmara Municipal de Vila Nova de Gaia. Gabinete de História e Arqueologia, 1986; COSTA, Francisco Barbosa da - S. Pedro de Pedroso nos séculos XVIII e XIX. Câmara Municipal de Vila Nova de Gaia. Junta de Freguesia de Pedroso, 2000; COSTA, Francisco Barbosa da - "Usos e Costumes nos

livros de visitações de algumas freguesias de Gaia”. Separata da Revista Gaia, vol. II. Vila Nova de Gaia: Gabinete de História e Arqueologia de Vila Nova de Gaia, 1984. pp. 281-290..; Titluos da Vezita q pertence ao Deado do Porto-PT/ADPRT/DIO/CABIDO- 